\title{
Formation and Stabilization of Vaterite Calcium Carbonate by Using Natural Polysaccharide
}

\author{
Mohamed El-Shahate Ismaiel Saraya ${ }^{1,2 *}$, Hanaa Hassan Abd El-Latif Rokbaa ${ }^{2,3}$ \\ ${ }^{1}$ Chemistry Department, Faculty of Science, Al-Azhar University, Cairo, Egypt \\ ${ }^{2}$ Chemistry Department, Faculty of Science and Arts, Al-Baha University, Al Makhwah, Saudi Arabia \\ ${ }^{3}$ Chemistry Department, Faculty of Science, Halwan University, Cairo, Egypt \\ Email: *mohamedsaraya37@gmail.com
}

How to cite this paper: Saraya, M.E.-S.I. and Rokbaa, H.H.A.E.-L. (2017) Formation and Stabilization of Vaterite Calcium Carbonate by Using Natural Polysaccharide. Advances in Nanoparticles, 6, 158-182. https://doi.org/10.4236/anp.2017.64014

Received: October 6, 2017

Accepted: November 19, 2017

Published: November 22, 2017

Copyright ( $) 2017$ by authors and Scientific Research Publishing Inc. This work is licensed under the Creative Commons Attribution International License (CC BY 4.0).

http://creativecommons.org/licenses/by/4.0/

(c) (i) Open Access

\begin{abstract}
This paper aimed to study the effects of natural polysaccharide (gum arabic, GA) on the formation of vaterite calcium carbonate and its stability in aqueous solution. Gum arabic is a macromolecule that has a high molecular weight and is amphoteric in character. A $0,2.5,5$ or $10 \mathrm{ml}$ of GA solution (30\%) was added to the calcium chloride solution with various initial concentrations to prepare the vaterite calcium carbonate. The calcium carbonate particles were characterized using FTIR, XRD, SEM, TEM and DSC-TG as well as calculation of phase contents. The results of XRD and FTIR analysis were showing that the presence of GA during the precipitation changes the behavior of calcium carbonate to form vaterite until at lower dose used. In addition, the molar content of vaterite increased at the expense of content of calcite with increasing the GA dose. There are slightly improvements in the vaterite content by increasing the initial concentration. The formed vaterite calcium carbonates composed of aggregates as broccoli-like or spherical shape and with particle size $1.6-2.5 \mu \mathrm{m}$ in diameter. TEM images showed that these aggregates composed of the sub spherical unit with diameter $15-30 \mathrm{~nm}$. The thermal behavior of prepared vaterite was conformed the mineral composition of these phases. The prepared calcium carbonate, which is formed in the presence of different doses of gum, has a stability in the aqueous solutions at different temperatures, as the analyzes indicated that a very small percentage of the vaterite were converted to calcite. The gum arabic prevented or depressed the transformation of vaterite to calcite through capped the surface of particles, i.e. it is more effective in stabilizing the vaterite phase with increasing in initial concentration and time.
\end{abstract}

\section{Keywords}

Gum Arabic, Vaterite, Characterization, Nanoparticles, Stability 


\section{Introduction}

Calcium carbonate is one of the most important minerals in the earth's crust [1]. Calcium carbonate has different phases such as calcium carbonate hexahydrate, calcium carbonate monohydrate, vaterite, aragonite and calcite. These polymorphs have different crystal structure and appearance [2]. Under all known conditions, the vaterite is metastable and has a higher solubility than the other $\mathrm{CaCO}_{3}$ polymorphs [3]. The transformation of meta-stable vaterite took place through dissolution process, followed by the crystallization of calcite. It is proved that the additives play an important role on the crystal growth rate, and could prevent the transformation from vaterite to calcite whether organic additives or inorganic additives [4]-[10]. Calcium carbonate is mainly used as filler in many industries that depend on its properties such as phase, morphology and size [11] [12] [13] [14]. Calcium carbonate nano particles were used in drug delivery and bone substitution [15] [16] [17], whereas vaterite has many properties that make it suitable for preparation of drug delivery carriers [18]. Vaterite has been used for the removal of dyes [19] [20] [21]; for adsorption of phosphate [22]; and metallic ions $\left(\mathrm{Cu}^{2+}\right.$ and $\left.\mathrm{Mn}^{2+}\right)$ [23].

Gum Arabic (GA) is the oldest known of all the tree gum exudates [24] and the Sudan is considered as the largest producer of gum arabic. Talha and hashab are the most common types of gum arabic [25] [26]. Gum Arabic is a polysaccharide compound that is found as a neutral to slightly acidic salt [27] [28], contains soluble fiber [29], has a $\mathrm{pH}$ of approximately $4.5-5.5$ [30], and is considered a comparatively weak polyelectrolyte [31]. Gum arabic is used in many applications as a thickener, stabilizer and emulsifier [32] [33]. Gum arabic is utilized as a dispersant for carbon nanotubes [34], $\alpha-\mathrm{Al}_{2} \mathrm{O}_{3}, \mathrm{TiO}_{2}, \mathrm{ZrO}_{2}$ [35], and $\mathrm{Fe}_{3} \mathrm{O}_{4}$ [36]. Copper [37]; and some of the noble metals nano particle are prepared in the presence gum arabic [38] [39]. In addition, gum arabic is used in preparation of calcite [40], and magnetic nanoparticles [41].

The current study aimed to study the effect of gum arabic on the spontaneous formation of vaterite and on its transformation to the most stable calcite at different initial concentrations of $\left[\mathrm{Ca}^{2+}\right]$ and at different incubation temperature with $\left[\mathrm{Ca}^{2+}\right] /\left[\mathrm{CO}_{3}^{2-}\right]$ molar ratio $1: 2$, constant flow rate and stirring.

\section{Experiment}

\subsection{Materials}

Gum arabic of the hashab type was obtained from Al-Nasr Company in Sudan and used without further purification. Calcium chloride dehydrates and sodium carbonate was analytical grade and used as received. Aqueous solutions of the reactants were prepared using doubly deionized water. Solution of gum arabic was prepared by dissolving GA powder in deionized water about $30 \mathrm{~g} / 100 \mathrm{ml}$ water.

\subsection{Calcium Carbonate Preparation}

Two litre glass flasks were used for preparation of calcium carbonate. Mixing 
was completed with the help of an overhead mechanical stirrer. The stirring speed for all the reactions was maintained at $1200 \mathrm{rpm}$. Vaterite was prepared by addition sodium carbonate solution to calcium chloride solution with different initial concentrations, $0.1,0.2$ and 0.3 mole at ambient temperature. The addition doses of the gum arabic solution were $0,2.5,5.0$ and $10.0 \mathrm{ml}$ of GA solution (30\%)/0.1 mole of $\mathrm{CaCl}_{2}$.

In order to study the stability of formed vaterite in the aqueous solution, the synthesized calcium carbonate retained in mother liquor for $24 \mathrm{~h}$. In addition, the incubation temperature effect on the stability of formed vaterite by the freshly prepared vaterite sample was dispersed in distilled water and refluxed near to $95^{\circ} \mathrm{C}$ for $2 \mathrm{~h}$. The prepared $\mathrm{CaCO}_{3}$ was washed with water, dried and kept for investigation by using FT-IR, XRD, SEM, TEM and thermal analyses.

\subsection{Instruments}

A JASCO Asia Portal-FT/IR-6300 Spectrometer using the KBr pellet method was used to record the FTIR spectra of the prepared samples. The sample was ground with dry $\mathrm{KBr}$ in a 1:100 mass ratio and pressed at 5 tons to form pellets. An XRD 7000 (Shimadzu Instruments, Japan) at a $2 \theta$ scan speed of $4^{\circ} \min ^{-1}, \lambda=$ $0.154 \mathrm{~nm}$ with $\mathrm{Cu} \mathrm{K} \alpha$ as a radiation source was used for determination of the crystallinity of the prepared calcium carbonates. Field emission scanning electron microscopy, a JEOL JSM 6360 DLA, Japan, and a transmission electron microscope ((TEM; Hitachi, H-800) where used for determination of the morphology and size of the prepared samples. DSC (NETZSCH STA 409 C/CD instrument) was used for investigating the thermal behaviours of some selected samples. The samples are studied up to $1000^{\circ} \mathrm{C}$, using a rate of $10^{\circ} \mathrm{C} / \mathrm{min}$ in an $\mathrm{He}$ atmosphere. The molar content (\%) of vaterite $\mathrm{CaCO}_{3}$ polymorphs was calculated as described in [42] [43].

\section{Results}

\subsection{Effect of Gum Arabic Concentration}

Figure 1(a) illustrates the XRD patterns of the prepared $\mathrm{CaCO}_{3}$ in presence of different dose, $0,2.5 \mathrm{ml}, 5.0 \mathrm{ml}$ and $10.0 \mathrm{ml}$ from $30 \%$ GA solution per $0.1 \mathrm{~mol}$ of $\mathrm{CaCl}_{2}$. In case of the absence GA, the peaks at $29.4^{\circ}, 36.0^{\circ}, 39.4^{\circ}, 43.1^{\circ}, 47.4^{\circ}$ and $48.5^{\circ} 2 \theta$ are attributed to the formation of calcite [44], while the peaks at $2 \theta$ values of $24.8^{\circ}, 27.0^{\circ}, 32.7^{\circ}, 43.8^{\circ}$ and $55.7^{\circ}$ are related to the vaterite [45]. This indicates that the precipitated calcium carbonate without GA is composed of a mixture of calcite and vaterite phases. The molar content of calcite and vaterite in this sample is $66 \%$ and $34 \%$, respectively. On the other hand, the XRD patterns of calcium carbonate samples prepared in presence of different doses of gum arabic have the characteristic peaks of vaterite only as a dominant phase. The molar content of vaterite in presence of GA was increased with increasing of dose to $100 \%$. This means that the addition of GA to the precipitation system prevented the transformation of vaterite to calcite. The FTIR spectra of the 


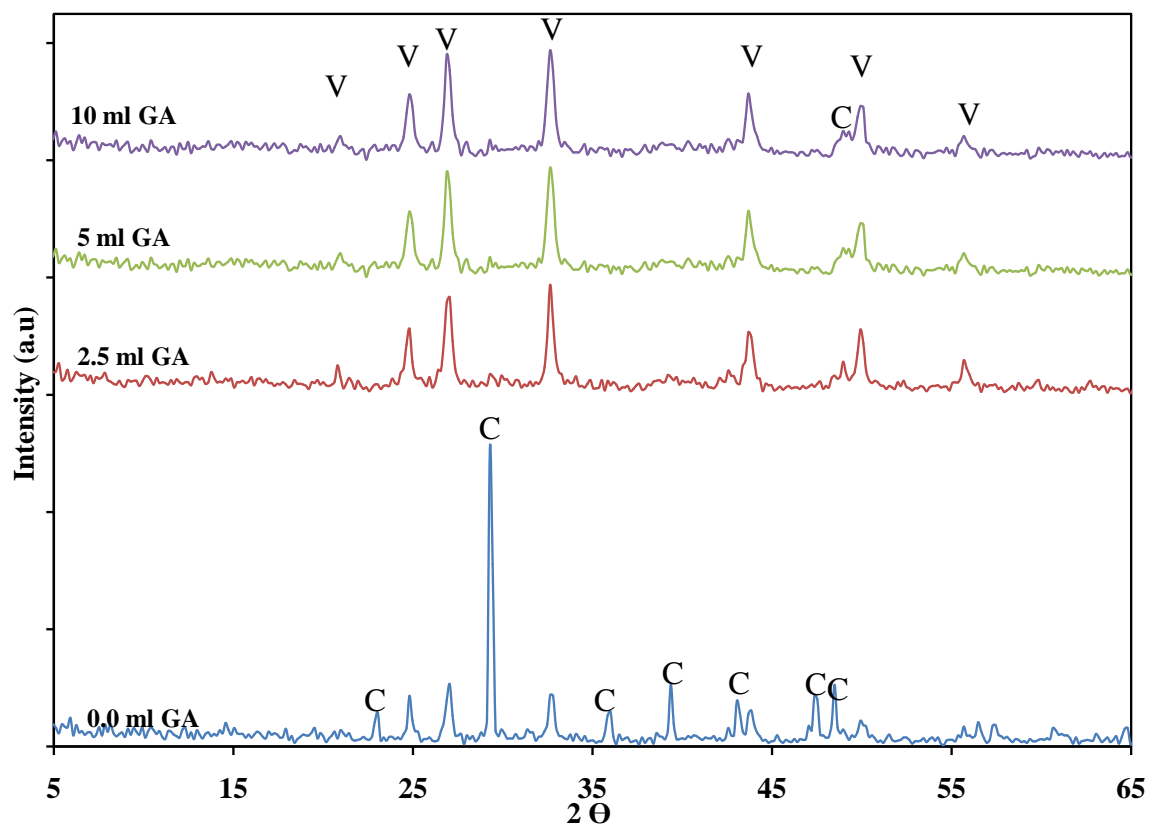

(a)

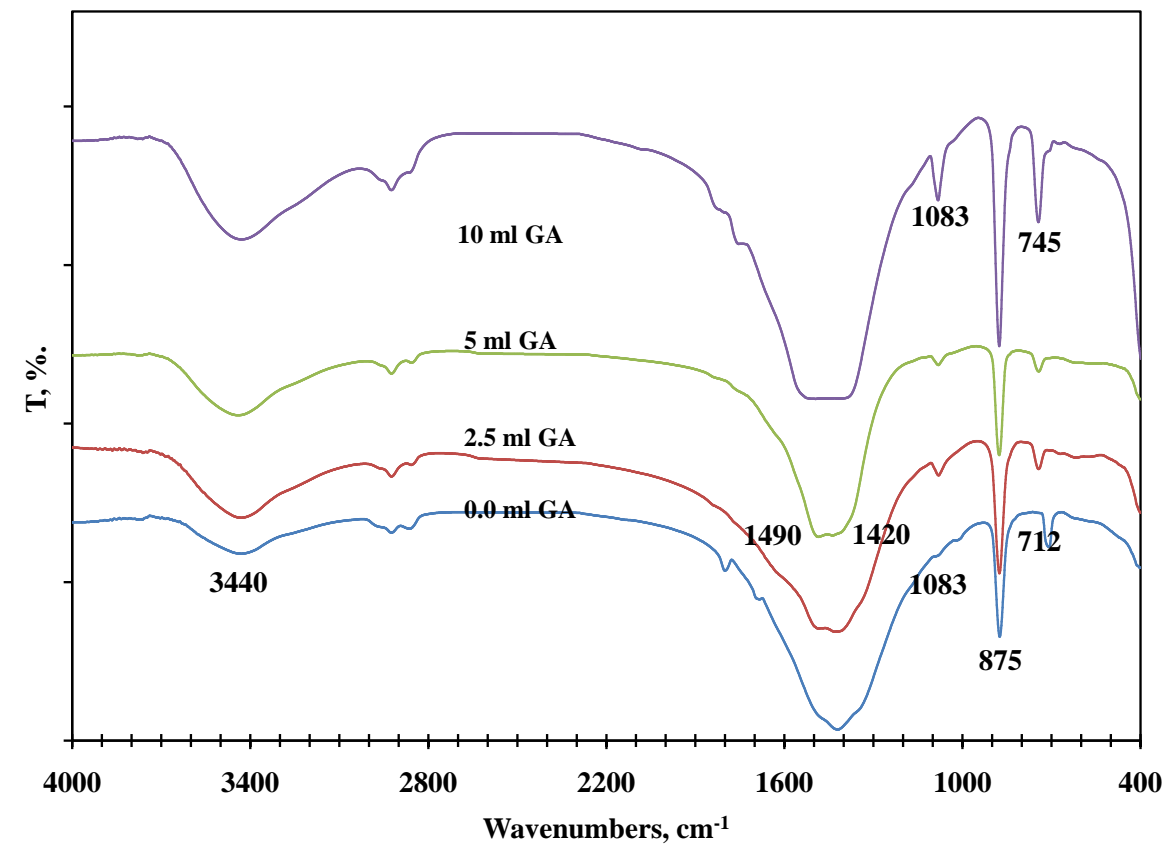

(b)

Figure 1. Powder X-ray diffractograms (a) and FTIR spectra (b) of calcium carbonate precipitated at $0.0,2.5,5.0$ and $10.0 \mathrm{ml}$ of GA/0.1 mole of $\mathrm{Ca}^{2+}$ solutions, $\mathrm{V}$ (vaterite) and C (calcite).

prepared $\mathrm{CaCO}_{3}$ with different doses of gum arabic are shown in Figure 1(b). The bands at 876 and $712 \mathrm{~cm}^{-1}$ are related to calcite phase [46], which appeared only in sample without GA. All samples, which are formed with different dose of GA, have absorption bands at 745,875 , and $1083 \mathrm{~cm}^{-1}$ with a splitted band at $1420 / 1490 \mathrm{~cm}^{-1}$ as indicating to a vaterite phase [47]. The intensity of vaterite 
bands was increased with concentration of gum up to $10 \mathrm{ml} / 0.1 \mathrm{~mol}$ of $\mathrm{Ca}^{2+}$ [48]. Also, the relatively ratio of $\mathrm{I}_{746} / \mathrm{I}_{712}$ increases with increasing of GA indicates that the content of polycrystalline vaterite increased [49].

Figures 2(a)-(c) show the SEM images of some selected samples. Figure 2(a) shows the SEM micrographs of the $\mathrm{CaCO}_{3}$ particles that obtained in absence of $\mathrm{GA}$, it is clearly shown that the $\mathrm{CaCO}_{3}$ particles have a regular plate-like calcite structure and an average length of approximately $3.7 \mathrm{~mm}$ and $3.3 \mathrm{~mm}$ in width. The SEM images of $\mathrm{CaCO}_{3}$ particles (Figure 2(b)), which are prepared with 2.5 $\mathrm{ml}$ of GA/0.1 mole of calcium chloride, have a typical broccoli-like agglomerate of vaterite, which is composed of subunits while that formed with $5.0 \mathrm{ml}$ of GA/0.1 mole composed of submits particles with only the spherical morphology of vaterite (Figure $2(\mathrm{c})$ ). This means the fraction of spherical vaterite increased with the increase of the concentrations of GA [50]. The surface morphology (smooth or rough) and crystal interior depend on the moment the GA is interfering with the crystallization process and polyelectrolyte chain length [51]. The TEM image of sample prepared without GA (Figure 2(d)) shows that the crystals consisted of rhombohedral crystals $85-95 \mathrm{~nm}$ in length and $55-75 \mathrm{~nm}$ in width, and its surface appeared as a sponge-like structure with minor amount of spherical particles that related to vaterite. TEM images of the vaterite precipitated with $5 \mathrm{ml}$ of GA/0.1 mole of calcium chloride sample showed the formation of mono-dispersed uniform spherical particles 15 to $30 \mathrm{~nm}$ in diameter.

As showing in Figure 3(a), the calcite DSC-TG curve, which formed without $\mathrm{GA}$, appeared a very small shoulder at $77^{\circ} \mathrm{C}$ that was related to removal of physical water, and the main endothermic peak at approximately $699^{\circ} \mathrm{C}$ indicating calcination of calcium carbonate. The weight loss percentage associated with this peak was $39 \%$ and the calculated calcium carbonate content was approximately $90 \%$. Also, Figure 3(b) illustrates the DSC-TG curves of sample prepared in presence of $5.0 \mathrm{ml} \mathrm{GA} / 0.1$ mole of $\mathrm{Ca}^{2+}$. The DSC curve of this sample reveals four endothermic peaks. The first peak, at $85^{\circ} \mathrm{C}$, may be related to removal of the physically water that adhered on the surface of the vaterite agglomerate [52]. The peaks at $125^{\circ} \mathrm{C}, 165^{\circ} \mathrm{C}$ are attributed to water formed in crystals inside the pores of vaterite [53]. These peaks are related to the approximately 5.0\% loss in weight. An exothermic signal at $397.3^{\circ} \mathrm{C}$ is related to converting vaterite to calcite. The last endothermic peak at $635^{\circ} \mathrm{C}$ and simultaneous mass change about (39.83\%) demonstrated the decomposition of calcium carbonate and release of carbon dioxide. The calcium carbonate content can be calculated from TG to be approximately $99.5 \%[54]$.

\subsection{Effect of the Initial Concentrations of $\mathrm{Ca}^{2+}$}

The Figure 4(a) displays the XRD patterns for calcium carbonate samples prepared from calcium chloride solution have initial concentrations $0.1,0.2$ and 0.3 moles in the presence of $5 \mathrm{ml}$ of GA/0.1 mole of $\mathrm{Ca}^{2+}$. As showing from Figure 4(a), All the samples have peaks at $24.8^{\circ}, 27.0^{\circ}, 32.7^{\circ}, 43.8^{\circ}$ and $55.7^{\circ} 2 \theta$ which 

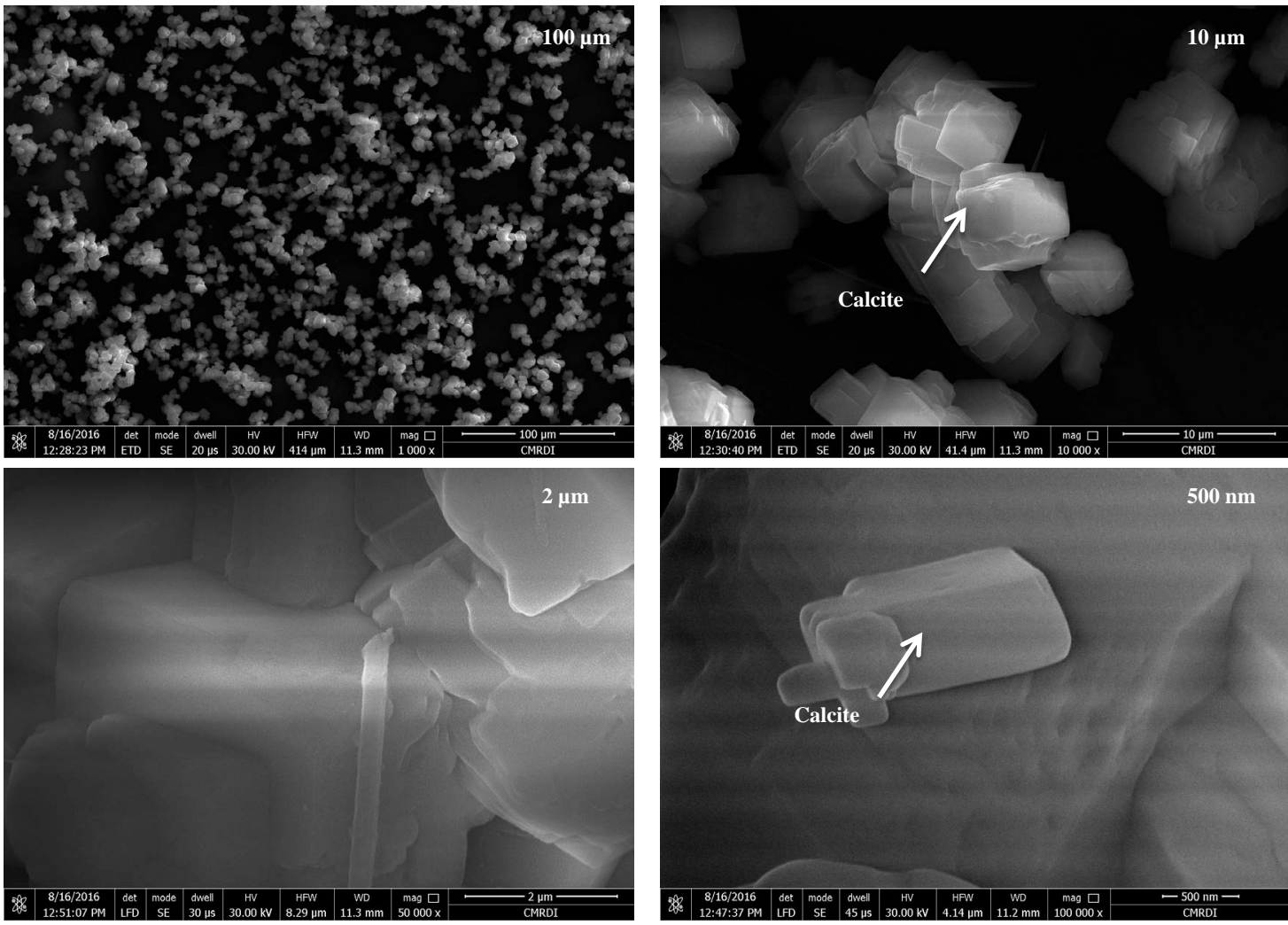

0 ml GA/0.1 mole $\mathrm{Ca}^{2+}$

(a)
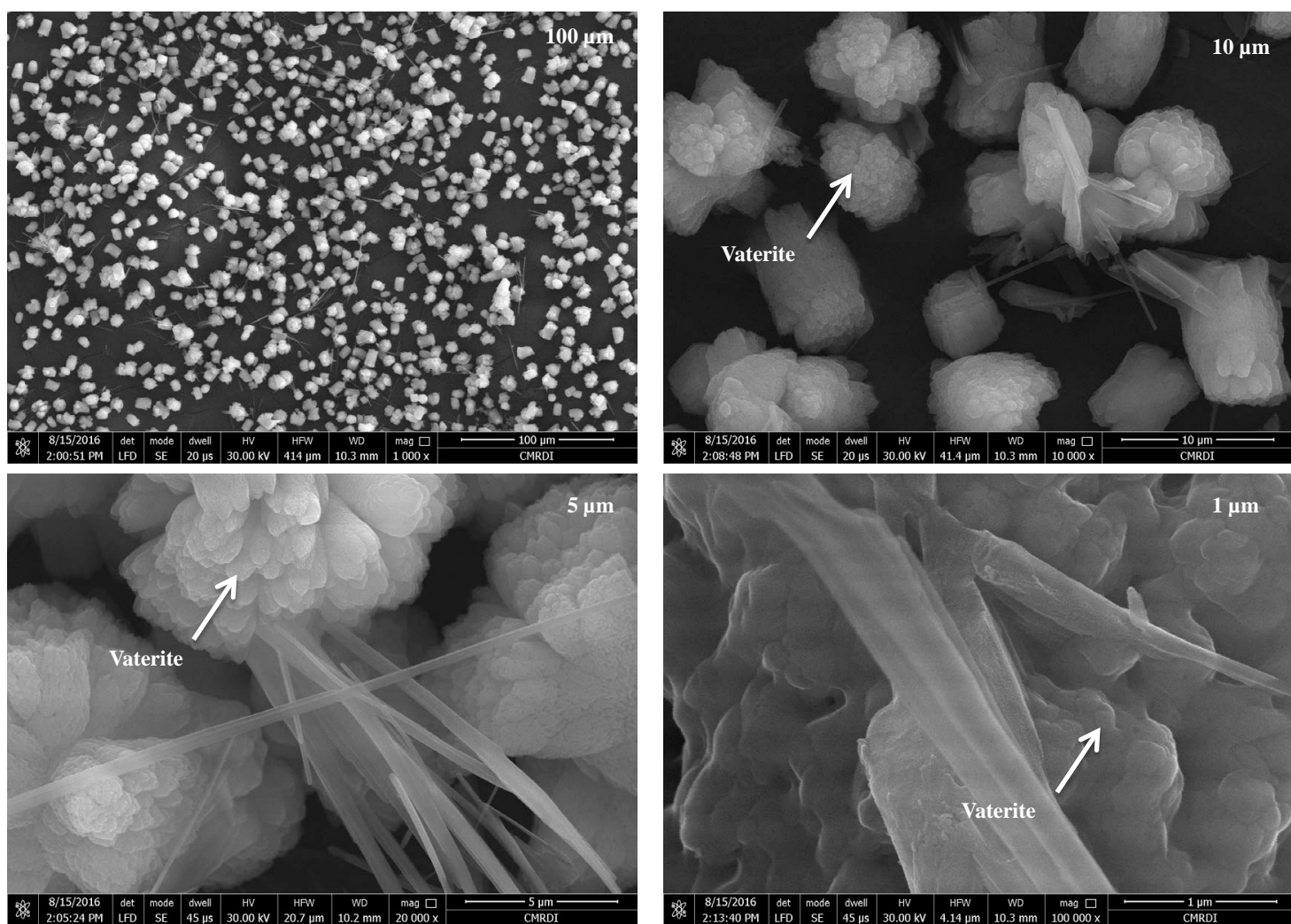

2.5 ml GA/0.1 mole $\mathrm{Ca}^{2+}$ 

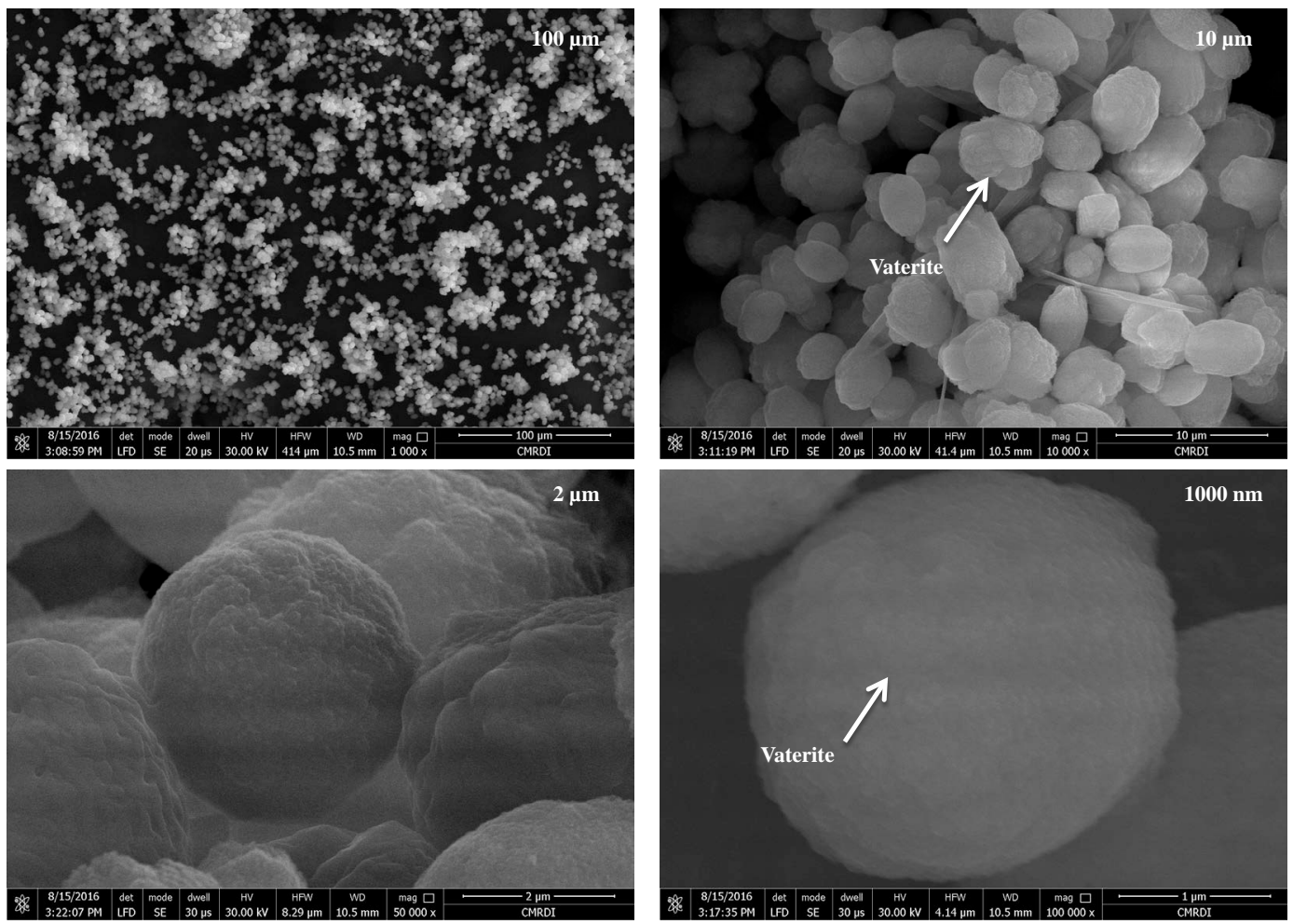

$5.0 \mathrm{ml} \mathrm{GA} / 0.1 \mathrm{~mole}^{2+}$

(c)
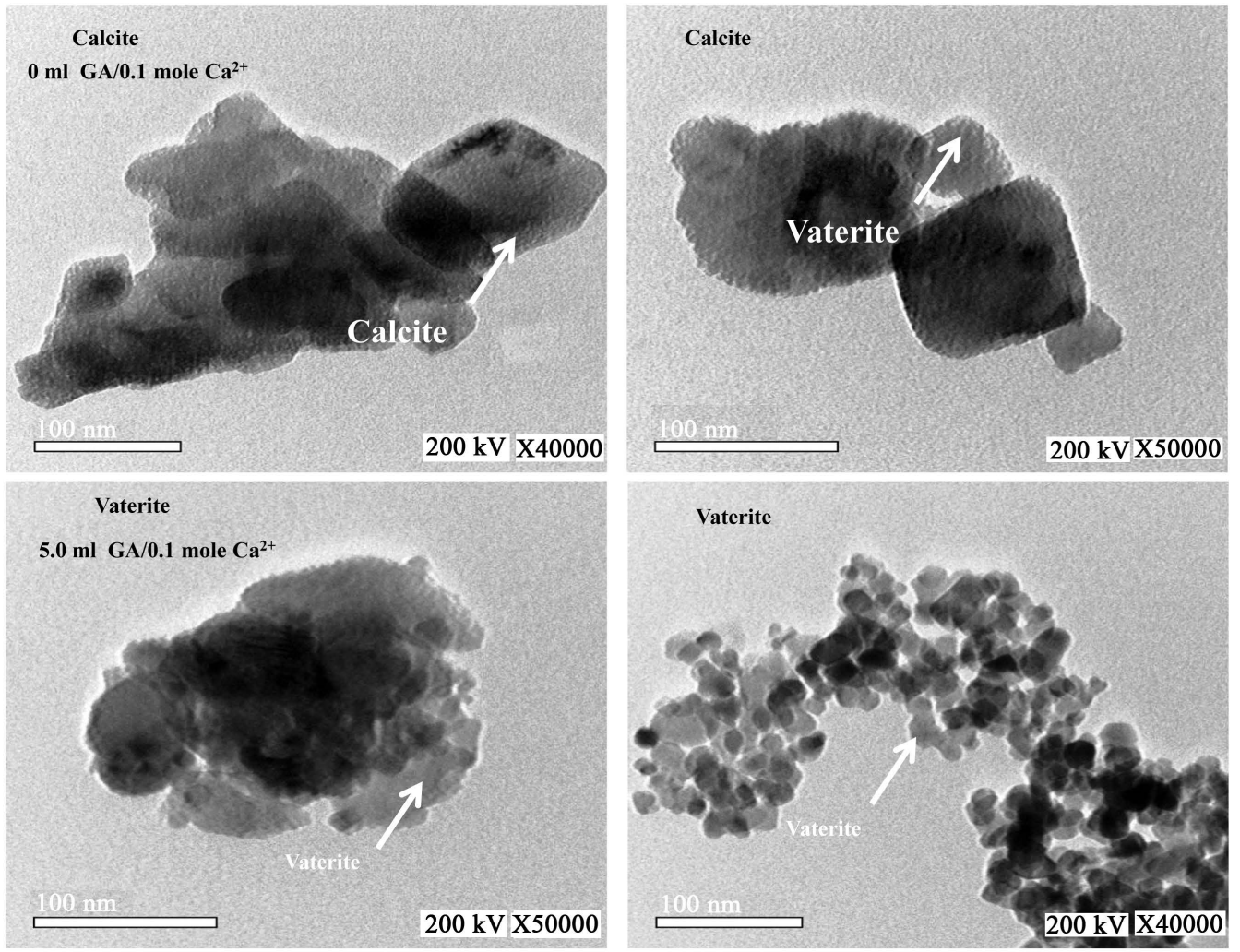

(d)

Figure 2. SEM images of calcium carbonate prepared with (a) $0.0 \mathrm{ml}$; (b) $2.5 \mathrm{ml}$; (c) $5.0 \mathrm{ml}$ of GA/0.1 mole of Ca ${ }^{2+}$ and (d) TEM images of calcium carbonate prepared with $0.0 \mathrm{ml}$ and $5.0 \mathrm{ml}$ of GA/0.1 mole of $\mathrm{Ca}^{2+}$. 


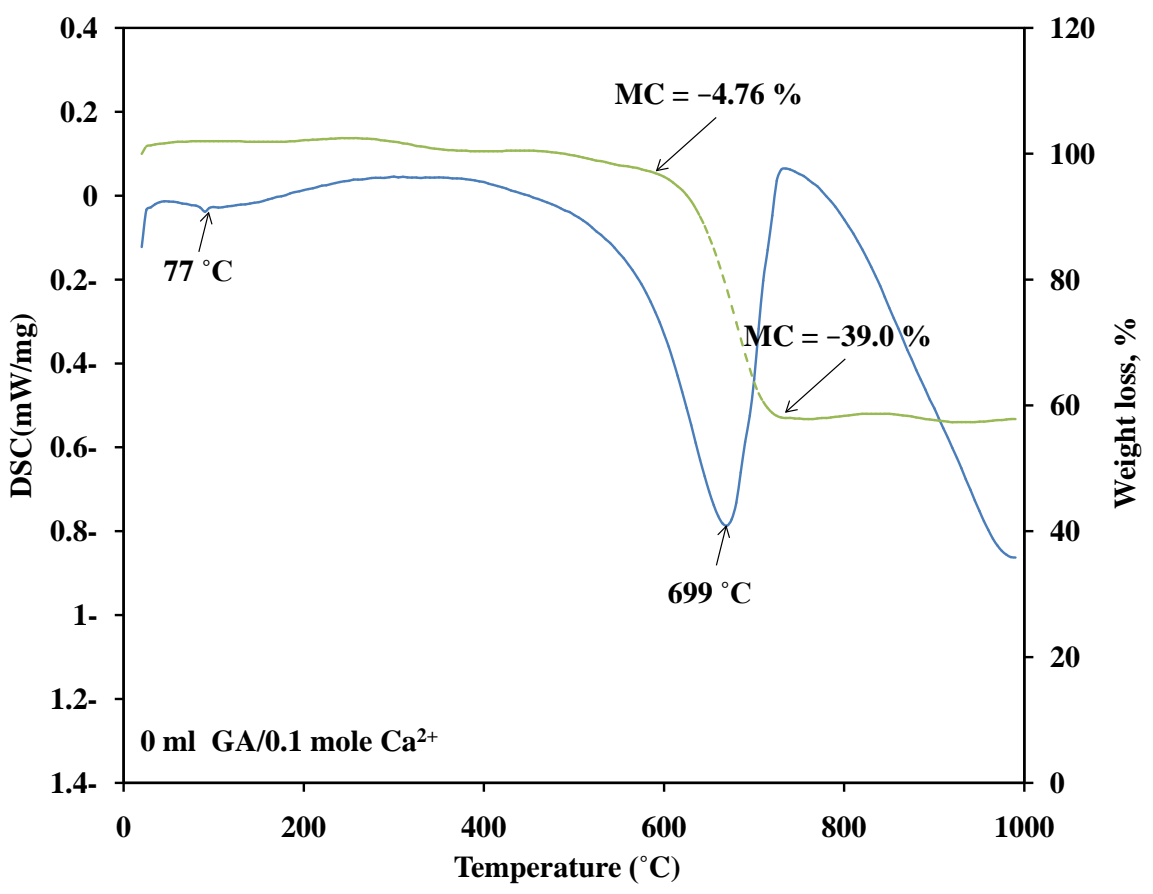

(a)

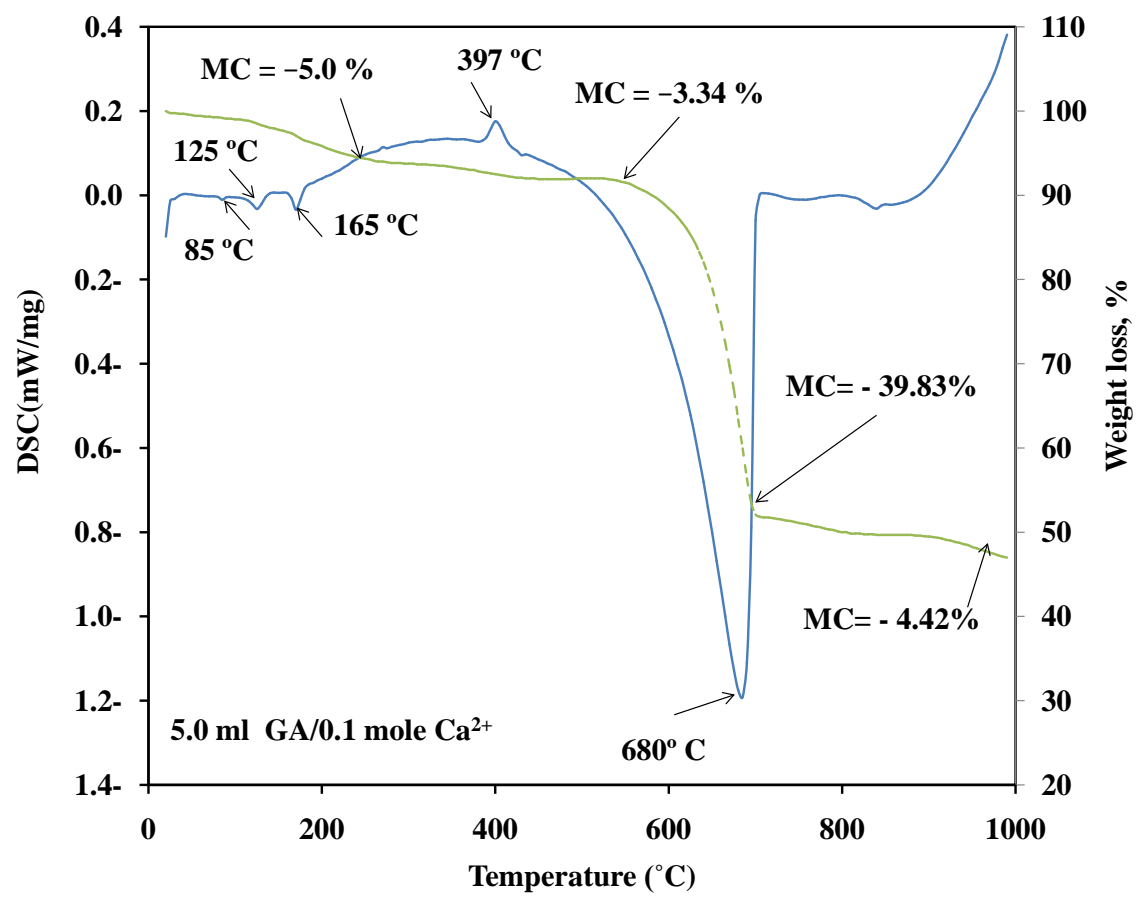

(b)

Figure 3. DSC-TG curves of calcium carbonate prepared without GA (a) and with $5.0 \mathrm{ml}$ (b) of GA/0.1 mole of $\mathrm{Ca}^{2+}$, DSC curves (solid line) and TG (dotted line).

are related to the vaterite calcium carbonate. In addition to the intensity of characteristic peaks of vaterite was increased slightly with increasing of the initial concentrations. The molar content of vaterite, for all samples, is about $100 \%$. The FTIR spectra of $\mathrm{CaCO}_{3}$ samples (Figure 4(b)), which were prepared with 


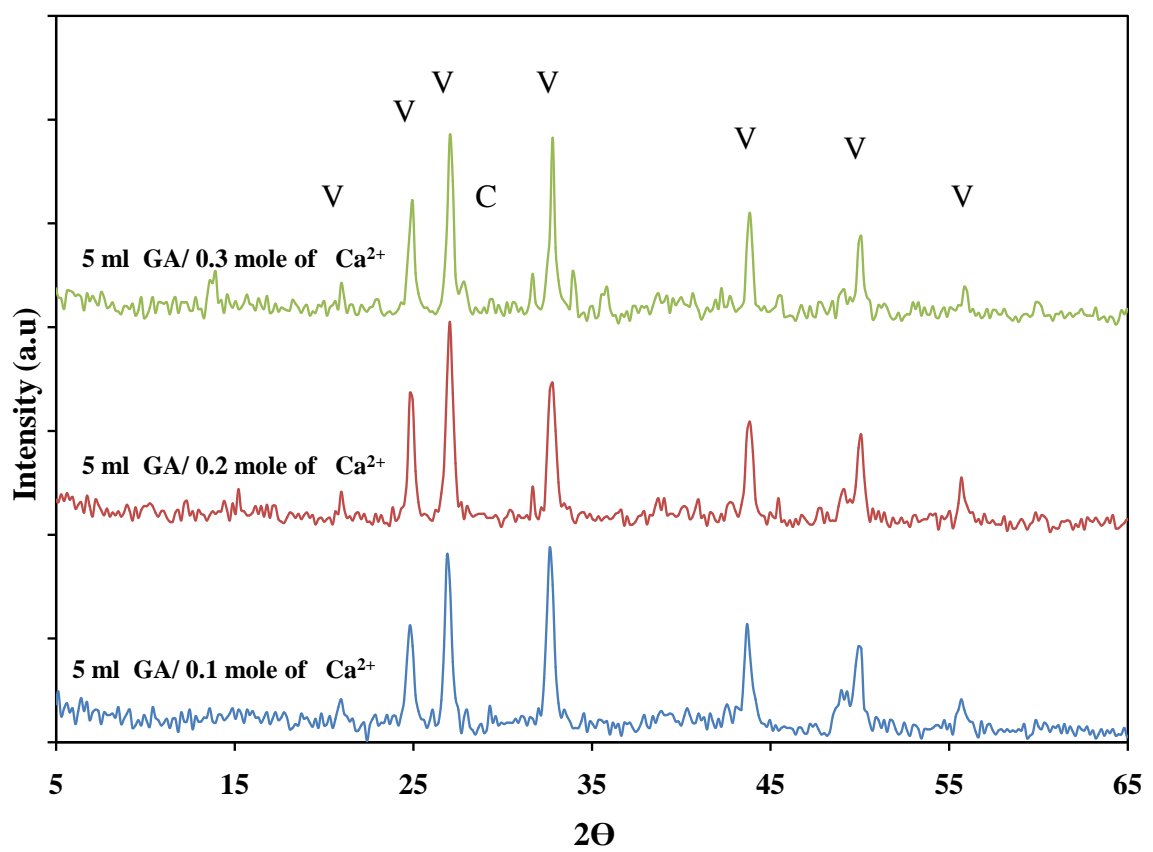

(a)

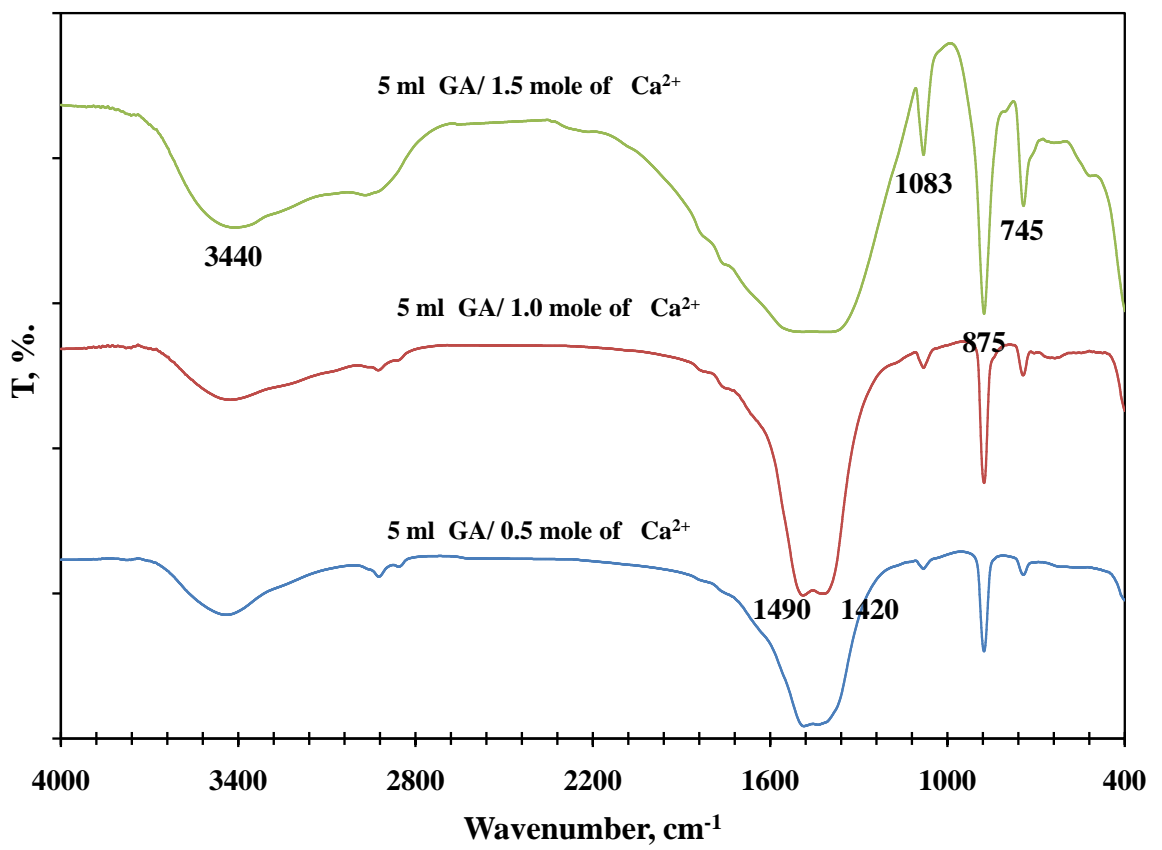

(b)

Figure 4. Powder X-ray diffractograms (a) and FTIR spectra (b) of calcium carbonate precipitated with $5 \mathrm{ml}$ of GA/0.1, 0.2 and 0.3 mole of $\mathrm{Ca}^{2+}$ solutions, $\mathrm{V}$ (vaterite) and $\mathrm{C}$ (calcite).

different initial concentrations of $\mathrm{Ca}^{2+}$, are pointed to the vaterite is the only one component in all samples at all concentration and also agreement with the results of X-ray diffraction analyses.

Figure 5(a) shows SEM images of calcium carbonate prepared from calcium chloride solution with initial concentration 1.0 mole in presence of $5 \mathrm{ml}$ of 

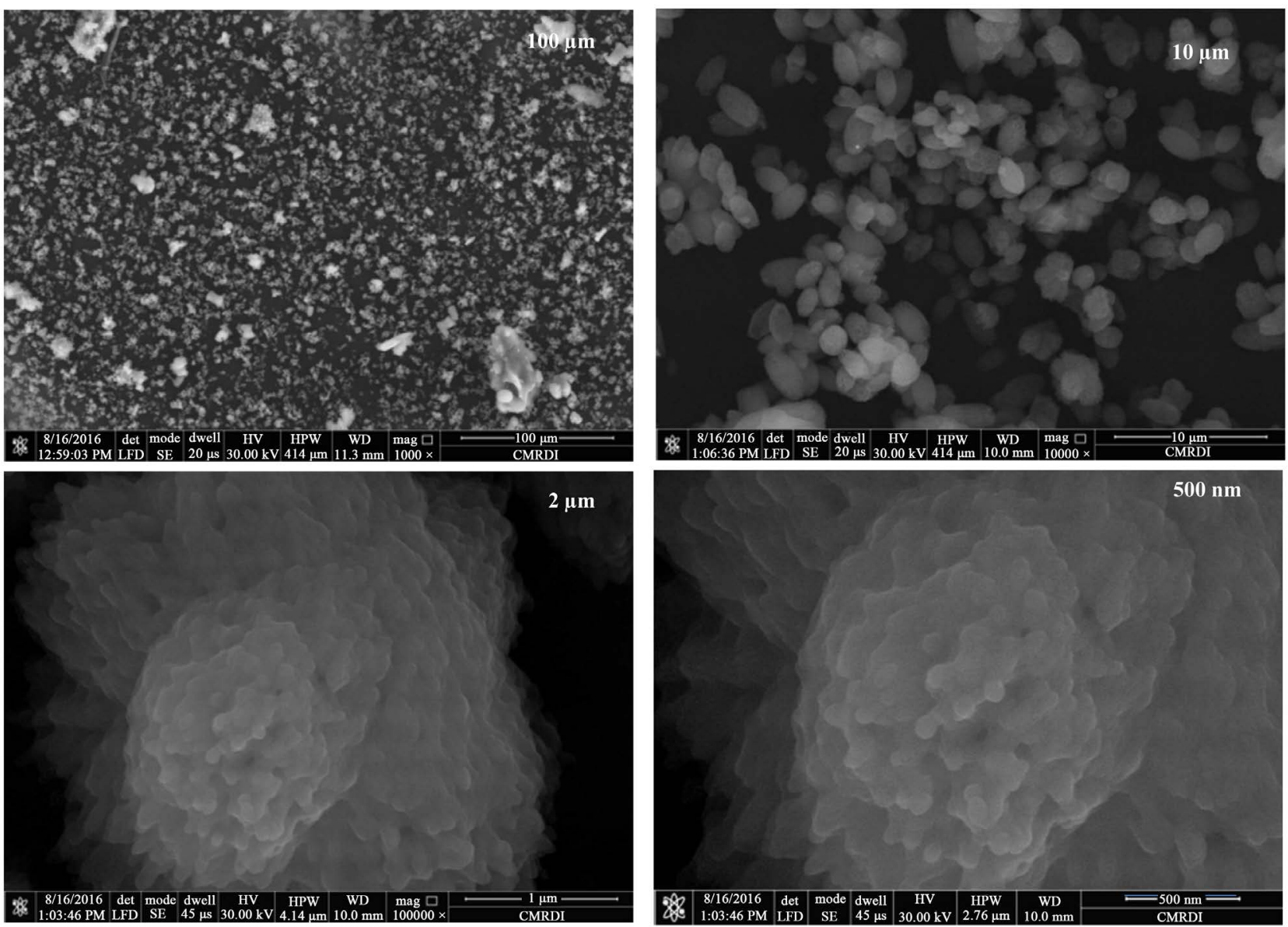

$5 \mathrm{ml} \mathrm{GA} / 1.0$ mole of $\mathrm{Ca}^{2+}$

(a)

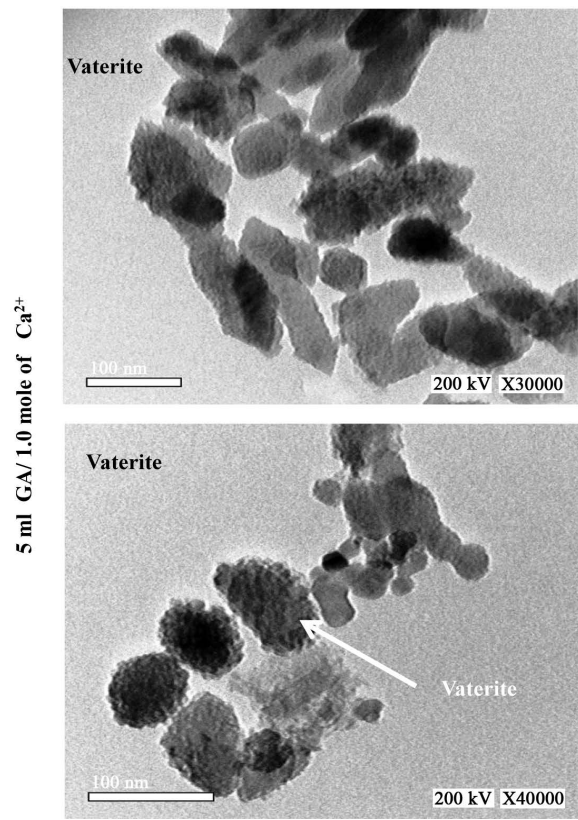

(b)

Figure 5. SEM images (a) and TEM images (b) of calcium carbonate prepared with $5 \mathrm{ml} \mathrm{GA} / 1.0$ mole of $\mathrm{Ca}^{2+}$, at room temp., for 24 hrs. 
GA/0.1 mole of $\mathrm{Ca}^{2+}$. As it show calcium carbonate has aggregate particles as broccoli-or cauliflower-like aggregates and have diameter near about 15 to 30 nm. TEM images (Figure 5(b)) shows these aggregate particles composed from subunits have spherical shape with particles size changed from $30-40 \mathrm{~nm}$.

Figure 6 shows the DSC-TG curves of the thermal behaviour of prepared calcium carbonate from calcium chloride solution with initial concentration 1.0 mole in presence of $5 \mathrm{ml}$ of GA/0.1 mole of $\mathrm{Ca}^{2+}$. It shows six endothermic peaks at $110^{\circ} \mathrm{C}, 117.4^{\circ} \mathrm{C}, 169^{\circ} \mathrm{C}, 388^{\circ} \mathrm{C}, 429^{\circ} \mathrm{C}$, and $671^{\circ} \mathrm{C}$. As shown above, this sample is composed of vaterite. The releasing of surface and crystalline water of vaterite and gaylussite was observed from signals at $110^{\circ} \mathrm{C}, 117.4^{\circ} \mathrm{C}$ and $169^{\circ} \mathrm{C}$. The TG curve shows the weight loss associated in this step to be approximately $5.5 \%$. The endothermic peaks at $388^{\circ} \mathrm{C}$ and $429^{\circ} \mathrm{C}$ indicated double hydrated crystal transformation from low temperature form into high temperature form. In this step, the mass reduction is related to ignition of GA and the loss of well-deep water in vaterite. The endothermic peak at $671^{\circ} \mathrm{C}$ is associated with the decomposition of $\mathrm{CaCO}_{3}$, where the mass change at this peak was $33.0 \%$ and the concentration of calcium carbonate was approximately $75 \%$ [55].

\subsection{Stability of Vaterite}

In order to study the effect of gum arabic on the stability of precipitated calcium carbonate, it was retained in the mother liquor for 24 hours. Figure 7 (a) illustrates the XRD patterns of $\mathrm{CaCO}_{3}$ particles which were prepared from calcium chloride solution its concentration is $0.1 \mathrm{~mol}$ in the presence of different doses of

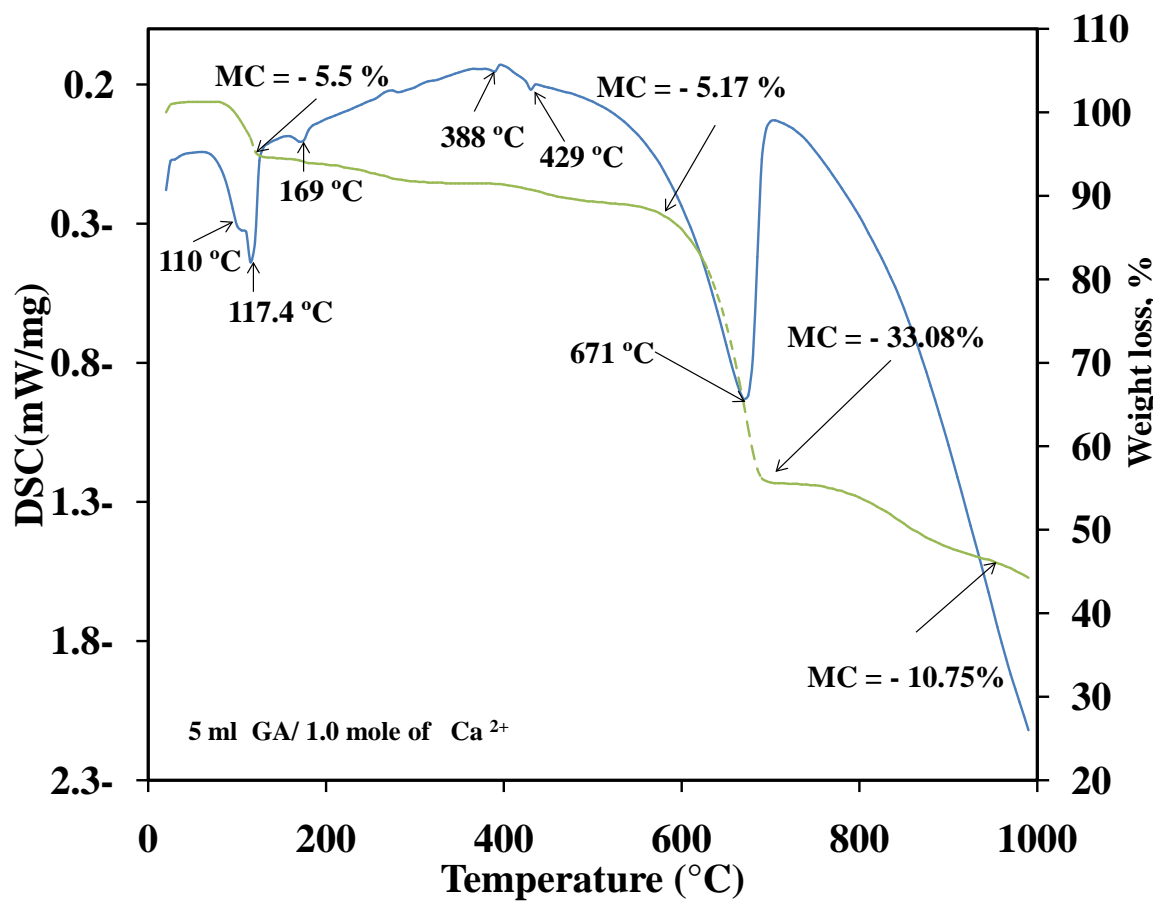

Figure 6. DSC-TG curves of calcium carbonate prepared with $5 \mathrm{ml} \mathrm{GA} / 1.0$ mole of $\mathrm{Ca}^{2+}$ : DSC curves (solid line) and TG (dotted line). 


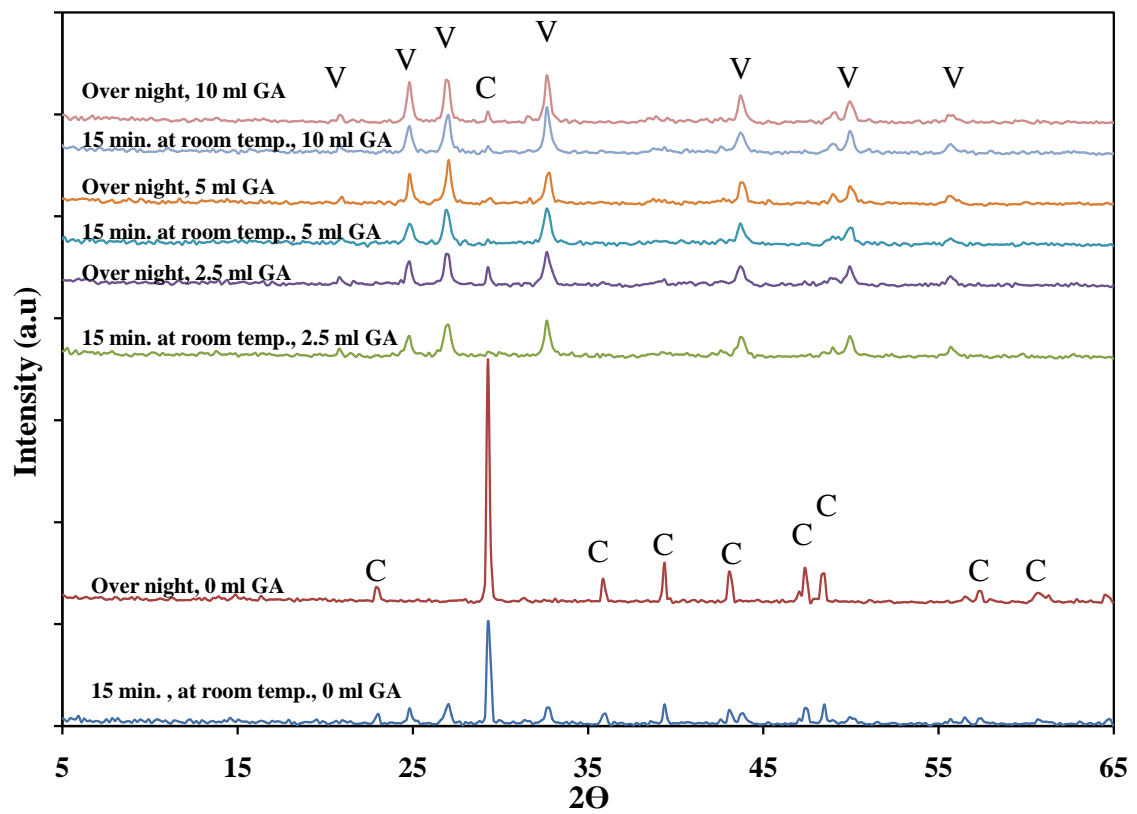

(a)

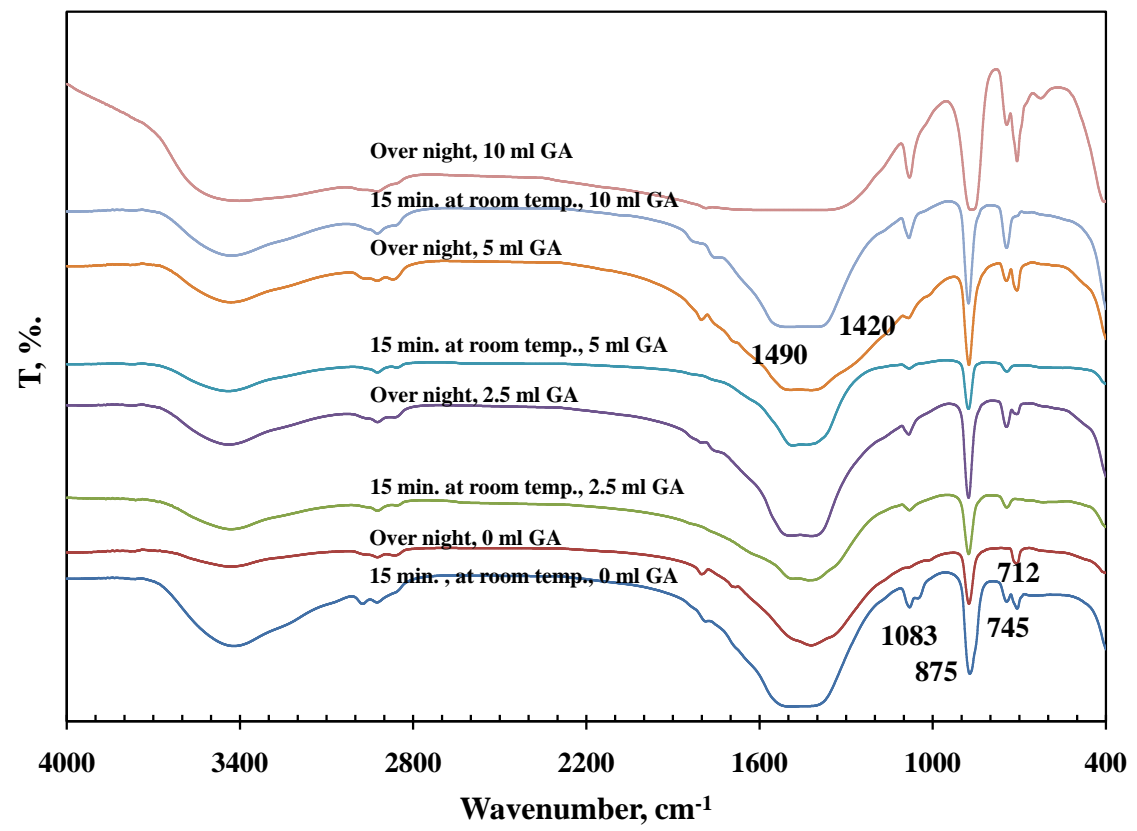

(b)

Figure 7. Powder X-ray diffractograms (a) and FTIR spectra (b) of calcium carbonate precipitated at $0.0,2.5,5.0$ and $10.0 \mathrm{ml}$ of GA/0.1 mole of $\mathrm{Ca}^{2+}$ solutions prepared at room temp for $15 \mathrm{~min}$. and $24 \mathrm{hrs}, \mathrm{V}$ (vaterite) and C (calcite).

GA solution. As show, the peaks at $29.4^{\circ}, 36.0^{\circ}, 39.4^{\circ}, 43.1^{\circ}, 47.4^{\circ}$ and $48.5^{\circ} 2 \theta$ are attributed to the formation of calcite which was appeared mainly in samples that retained in mother liquor. This is indicted to the converting the vaterite to calcite whereas the $\mathrm{CaCO}_{3}$ samples that prepared without GA turned to calcite completely after $24 \mathrm{~h}$, with the molar content of calcite $34 \%$ but after 24 hours in the mother liquor has become $100 \%$. The intensities of the characteristic peaks 
of calcite decreased with addition of GA. The calcite contents are 100, 34, 6, and $4 \%$ with GA dose 0, 2.5, 5.0 and $10.0 \mathrm{ml}$, respectively. On the other hand, FTIR spectra (Figure 7(b)) show the sample that incubated for $24 \mathrm{hr}$ in absences of GA was completely converted to calcite (the bands at 875 and $712 \mathrm{~cm}^{-1}$ ). While in the presence of GA there are traces of calcite was appeared.

\subsection{Effect of Incubation Temperature}

Figure 8 displays the XRD patterns of calcium carbonated incubated at $95^{\circ} \mathrm{C}$ for 120 min. Figure 8(a) shows the XRD patterns of sample prepared with different dose of GA and incubated at ambient temp and at $95^{\circ} \mathrm{C}$. It shows that the calcium carbonate prepared in the absence of gum arabic at room temperature contains a mixture of calcite $(40 \%)$ and vaterite $(60 \%)$ but when prepared at $95^{\circ} \mathrm{C}$, the aragonite phase appeared $(30 \%)$, located at $2 \theta 26.19^{\circ}, 27.16^{\circ}, 37.8^{\circ}$, $38.5^{\circ}$ and $45.87^{\circ}$ [56] while calcite and vaterite content decreased to $48 \%$ and $22 \%$, respectively. This is mainly due to transform of vaterite to calcite and to aragonite, where at elevated temperature which stabilized the aragonite phase [51]. With addition $2.5 \mathrm{ml}$ of GA to precipitation solution, at room temperature, the vaterite phase became the main component $(100 \%)$ of calcium carbonate to vaterite but at $95^{\circ} \mathrm{C}$ the sample composed of 56\% vaterite, $29 \%$ aragonite and $15 \%$ calcite. This is contributed to the dissolution and recrystallization of vaterite to aragonite and calcite. As the dose of GA increases, the dissolution and recrystallization process of vaterite prevented whereas the content of vaterite was slightly changed from $100 \%$ to $94 \%$ and $95 \%$ for 5 and $10 \mathrm{ml}$ of GA, respectively. This confirms the ability of GA molecules to absorb and bind to the surface of vaterite calcium carbonate particles and prevent them from switching to other phases despite the high temperature of the medium that helps to transform process. Figure $8(\mathrm{~b})$ illustrates the FTIR spectra of the calcium carbonate samples that incubated at ambient temperature and $95^{\circ} \mathrm{C}$. The characteristic bands of calcite and aragonite were appeared in samples without and with $2.5 \mathrm{ml}$ of GA after fluxes at $95^{\circ} \mathrm{C}$ for $2 \mathrm{hr}$ but did not appear with increasing GA dose. These spectra are conformed on that the GA molecules adsorbed strongly on the surface of vaterite particles and prevent the dissolution and recrystallization process either to calcite or aragonite. However it is known that the thermal treatment or elevation incubation temperature help to forming the aragonite phase.

Figure 9(a) shows the XRD patterns of calcium carbonate precipitated with 5 $\mathrm{ml} \mathrm{GA} / 0.1,0.2$ and $0.3 \mathrm{~mol}$ of $\mathrm{Ca}^{2+}$ at $95^{\circ} \mathrm{C}$. It is shown that at low initial concentration aragonite phase only was formed that appears from the peaks located at $2 \theta 26.19^{\circ}, 27.16^{\circ}, 37.8^{\circ}, 38.5^{\circ}$ and $45.87^{\circ}$ ) [56]. While the vaterite phase formed with increasing concentration of $\mathrm{Ca}^{2+}$ with minor amount of calcite. This is undoubtedly due to the properties of gum arabic, which works to form the vaterite and prevent its transformation into calcite. The absorption bands at 700 , 855 , and $1083 \mathrm{~cm}^{-1}$ are related to aragonite (Figure 9(b)) that shows the formation of aragonite phase in the presence of $5 \mathrm{ml} \mathrm{GA}$ at the lowest concentration of $\mathrm{Ca}^{2+}$. While with initial concentration of $\mathrm{Ca}^{2+}$ increases only vaterite phase 


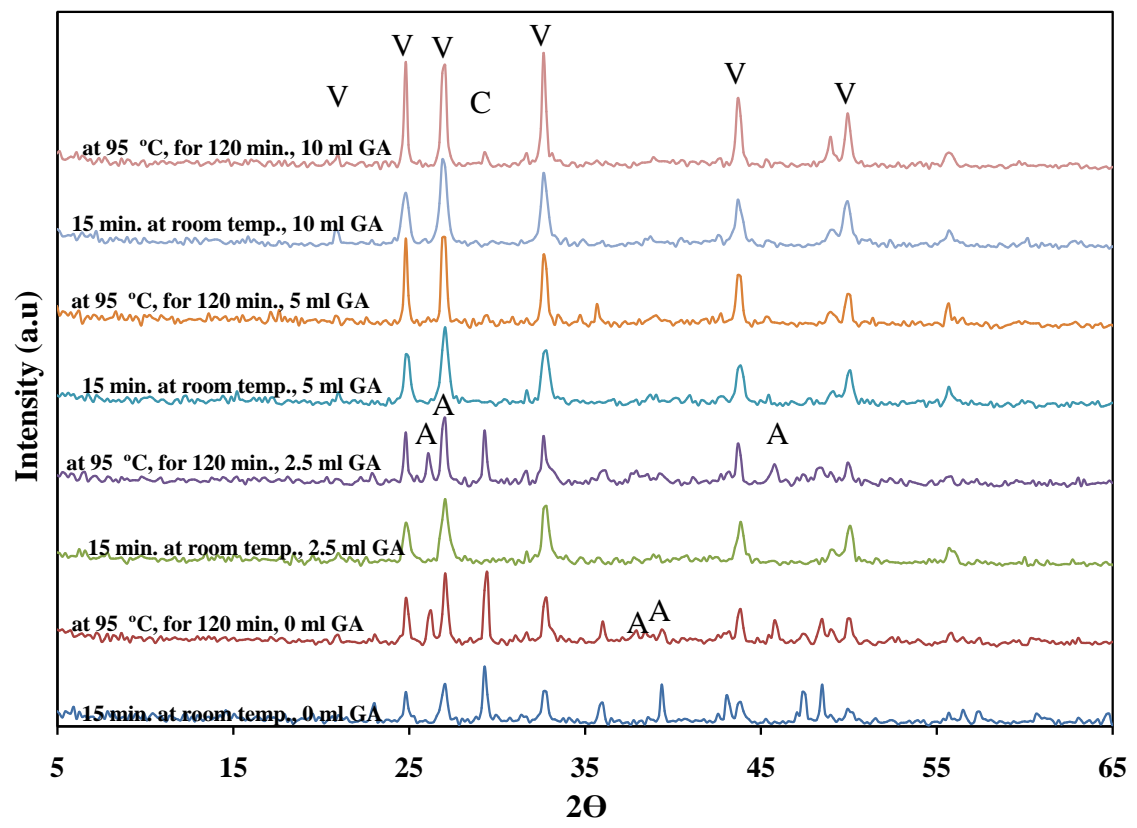

(a)

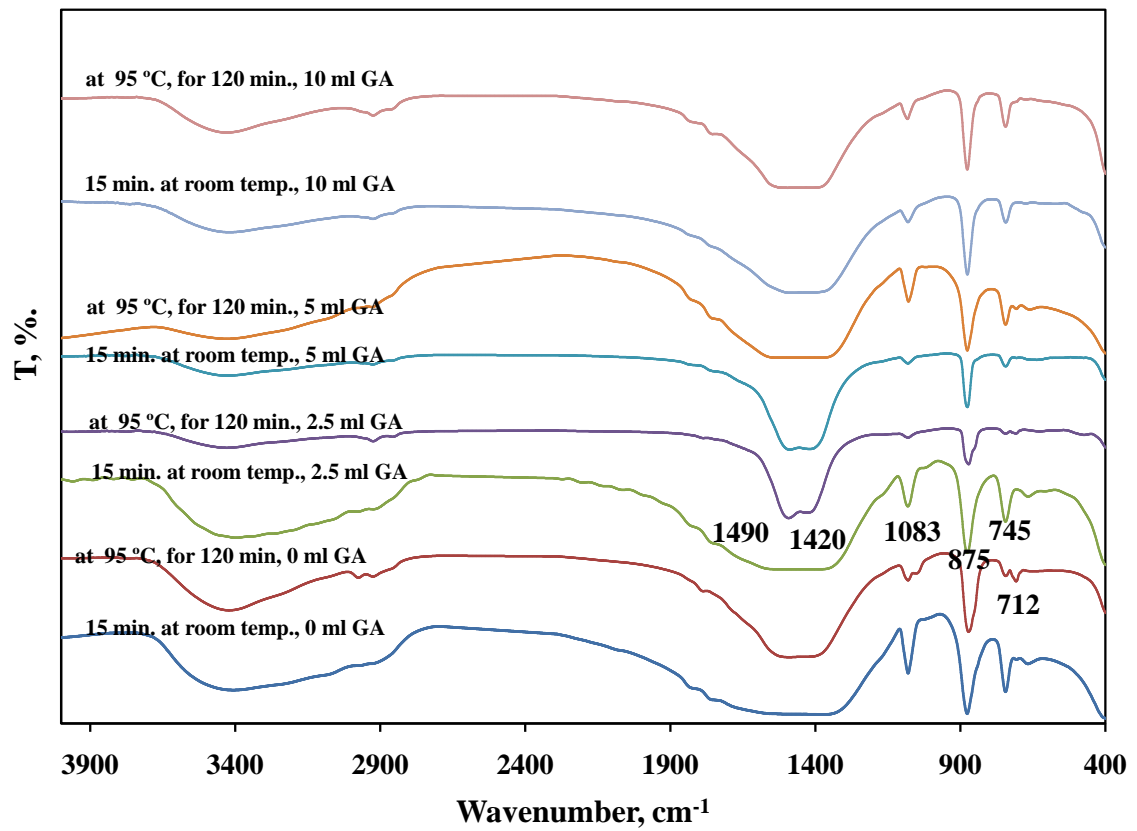

(b)

Figure 8. Powder X-ray diffractograms (a) and FTIR spectra (b) of calcium carbonate precipitated at $0.0,2.5,5.0$ and $10.0 \mathrm{ml}$ of GA/0.1 mole of $\mathrm{Ca}^{2+}$ solutions prepared at room temp for $15 \mathrm{~min}$. and $95^{\circ} \mathrm{C}$ for $120 \mathrm{~min}$., $\mathrm{V}$ (vaterite) and $\mathrm{C}$ (calcite).

formed. The SEM and TEM images of the aragonite prepared at $95^{\circ} \mathrm{C}$ in presence $5 \mathrm{ml}$ of GA/0.1 mol Ca${ }^{2+}$ are displayed in Figure 10(a). The SEM images are shown only particles with needle morphology or the big spindles of aragonite that composed from nanoparticles about $75-150 \mathrm{~nm}$. TEM images of aragonite show the individual needle-like shape that is composed of separate spindled continuous filaments or as a fingerprint. 


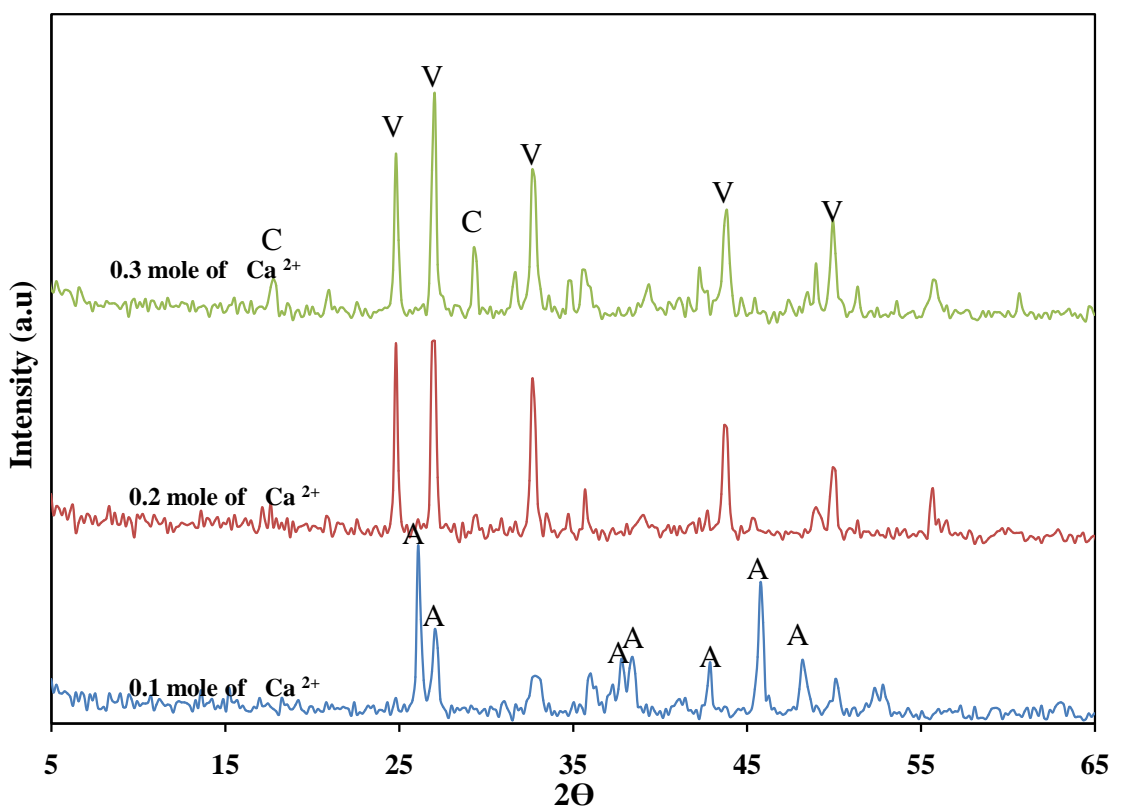

(a)

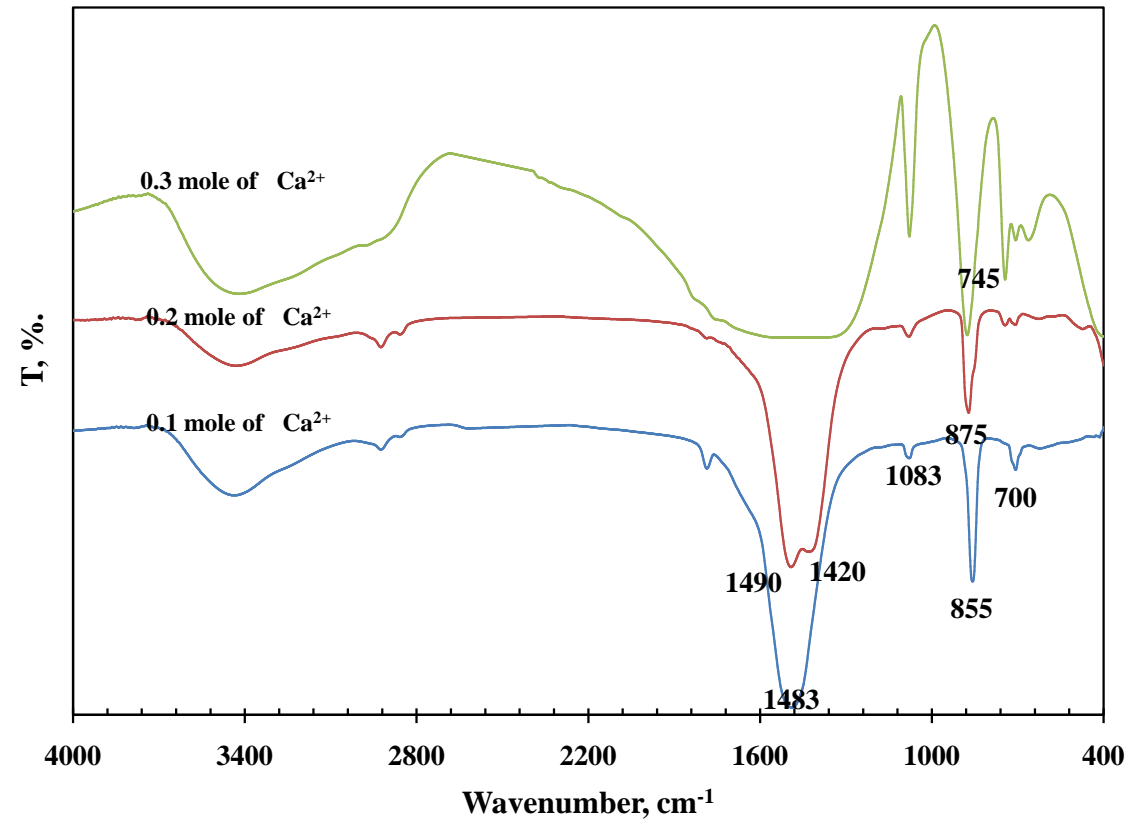

(b)

Figure 9. Powder X-ray diffractograms (a) and FTIR spectra (b) of calcium carbonate precipitated at $95^{\circ} \mathrm{C}$ for $120 \mathrm{~min}$. with $5 \mathrm{ml} \mathrm{GA} / 0.1,0.2$ and $0.3 \mathrm{~mol} \mathrm{Ca}^{2+}, \mathrm{V}$ (vaterite) and $\mathrm{C}$ (calcite).

The DSC curve of aragonite (Figure 10(b)) clearly shows four endothermic peaks. The peaks at $120^{\circ} \mathrm{C}$ and $200^{\circ} \mathrm{C}$ are related to the evaporation of occluded water and decomposition of gum arabic [57]. According to the TG curves, the reduction in mass in this step was approximately $24 \%$. Aragonite is a metastable phase of calcium carbonate and converted to calcite upon heating, as shown from the peak at $410^{\circ} \mathrm{C}$. This process is endothermic. The water appeared to be 

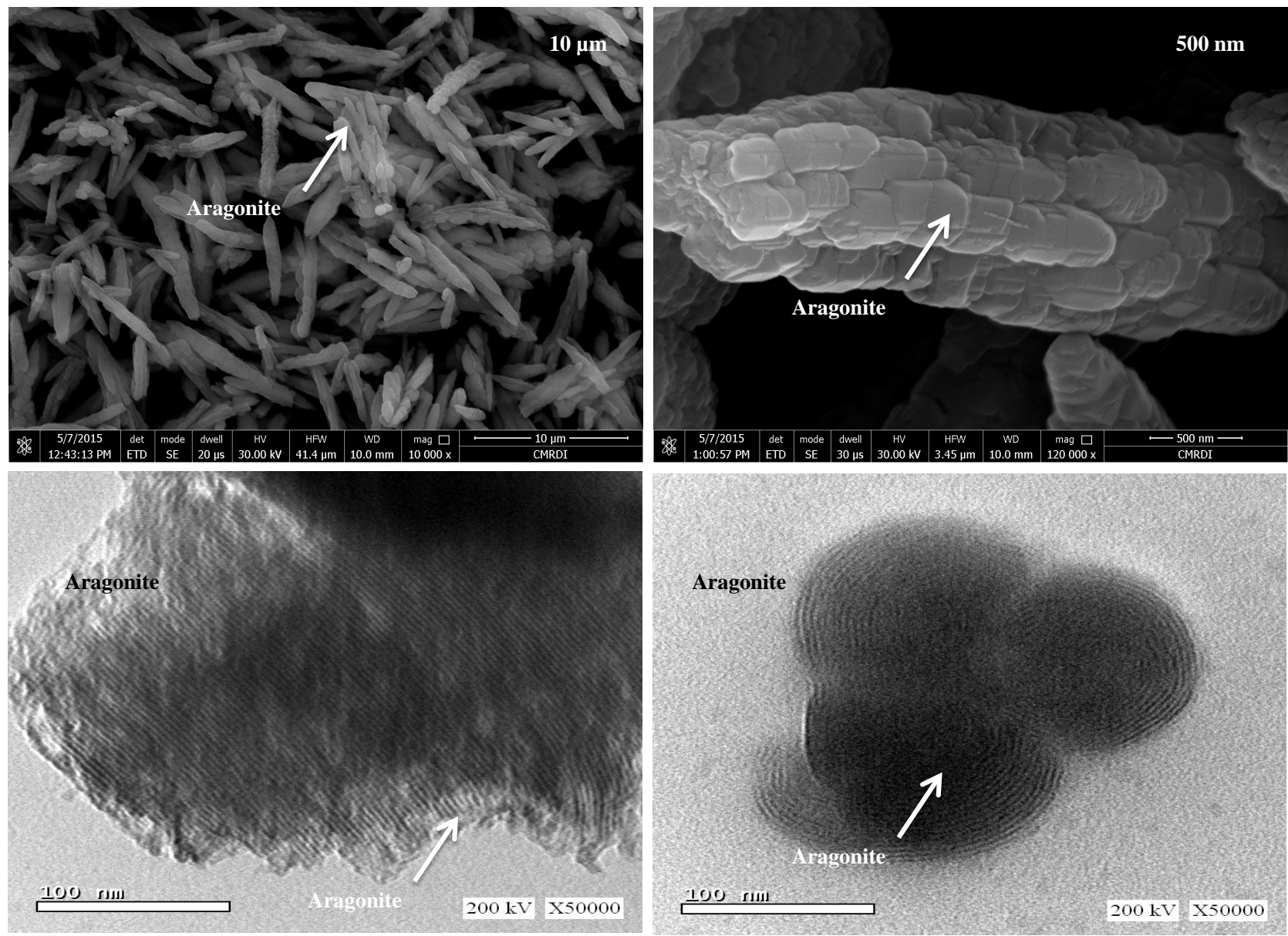

(a)

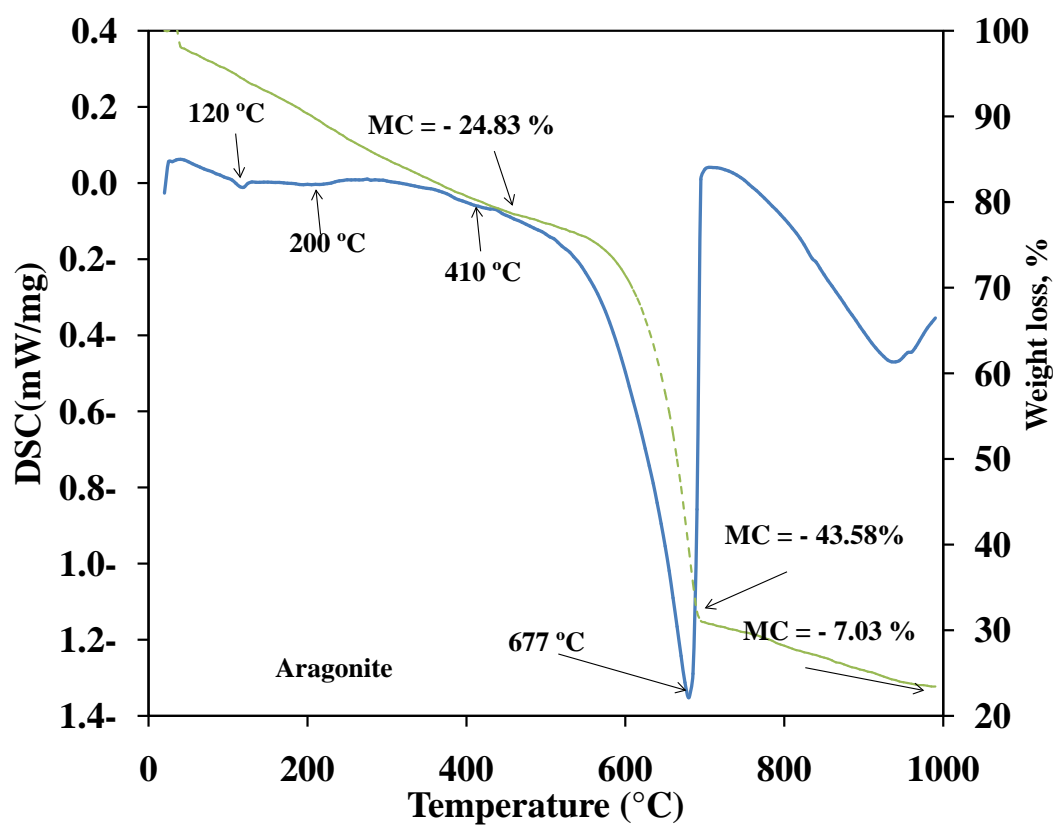

(b)

Figure 10. SEM images and TEM images (a) DSC-TG curves: DSC curves (solid line) and TG (dotted line); (b) of calcium carbonate prepared with $5 \mathrm{ml} \mathrm{GA} / 1.0$ mole of $\mathrm{Ca}^{2+}$ at $95^{\circ} \mathrm{C}$ for 120 . 
released uniformly during the transformation process and didn't cause any distortion of the DSC curve [58]. The endothermic peak at $677^{\circ} \mathrm{C}$ is related to the calcination of calcium carbonate. The mass change according to this peak was approximately $43.9 \%$, which indicate that the concentration of calcium carbonate was approximately $99.5 \%$.

\section{Discussion}

The chemical composition of organic compounds plays an important role in the crystallization process and hence the form and type of product, whereas these additives change the properties of the solid-liquid interface during the crystallization and recrystallization process. The presence of $-\mathrm{COOH},-\mathrm{OH}$ and $-\mathrm{NH}_{2}$ are the main functional groups in gum arabic acquire it slightly acidic properties. The Wattle blossom model of gum arabic [59] indicates that it consists of arabinogalactan (GA), arabinogalactan protein (AGP), and glycoprotein (GP) (Figure 11(a)), this means GA has a hydrophilic and hydrophobic species. The $\mathrm{pH}$ value of the native gum arabic solution was 4.58 , and its isoelectric point was 1.8. At this point, the carboxylic and amino groups carry negative and positive charges, respectively [60]. The carboxylic groups become fully protonated and less hydrophilic in acidic media at $\mathrm{pH}<\mathrm{pKa}$, whereas at $\mathrm{pH}>\mathrm{pKa}$, the carboxylic groups become ionized and have lower hydrophobicity. Thus, the GA molecule will compress and expand [61] [62], Figure 11(b). These conditions help to form strong bonding between calcium ions and gum arabic molecules as shown in Figure 11(c). Dror et al. was reported [63], in aqueous systems of GA, which electrostatic repulsion does not play a controlling role in emulsion stabilization, but steric repulsion might be the main mechanism for particle stabilization. Amorphous calcium carbonate is formed once the carbonate ions are added to the calcium ions solution, which is directly converted to the hydrated calcium carbonate. These forms are converted into vaterite or aragonite according to the precipitation conditions and then turned into the most stable form of calcite. At the first period of the spontaneous process, the nuclei formed will act as seeds and will further grow to larger sizes before aggregation and forming secondary particles. The presence of GA resulted in the capture of calcium ions by fully ionized carboxylic groups to form a Ca ${ }^{2+}-\mathrm{GA}$ complexes, $\left(\mathrm{GA}(\mathrm{COO}-)+\mathrm{Ca}^{2+} \leftrightarrow\right.$ $\mathrm{GA}(\mathrm{COO}) \mathrm{Ca}^{2+}$. These complexes are formed rapidly and make the surface of the aggregates the most active site for nucleation. It is well known that vaterite crystals predominately grow from supersaturated solution. The $\left(\begin{array}{lll}0 & 0 & 1\end{array}\right),\left(\begin{array}{lll}1 & 0 & 1\end{array}\right)$, and $\left(\begin{array}{lll}1 & 1 & 0\end{array}\right)$ planes of vaterite are positively charged and contain exposed $\mathrm{Ca}$ ions; thus, complex adsorbs preferentially on these faces and block further growth to another axes and prevent vaterite transformation [64]. By further vaterite growing under GA complexes, pores of the spherical vaterite particles are filled, giving rise to the raspberry shapes by aggregation of several spheres. At high concentrations of GA, the vaterite is the most formed phase. Whereas, the GA molecules becomes more incorporated into calcium carbonate crystal facets and a 


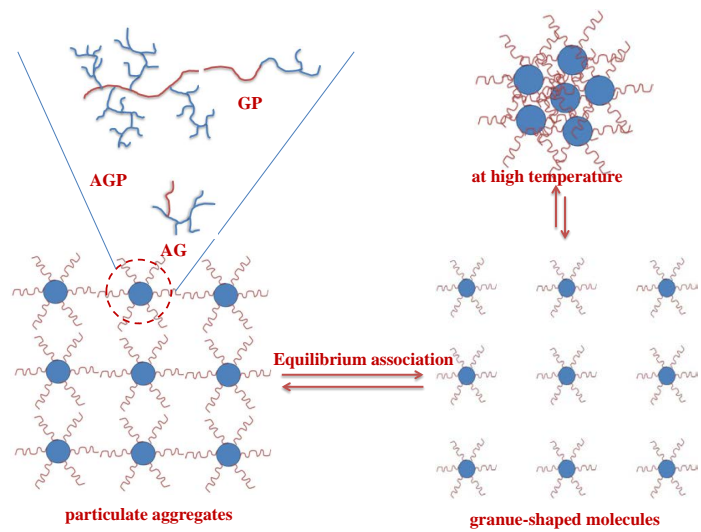

(a)

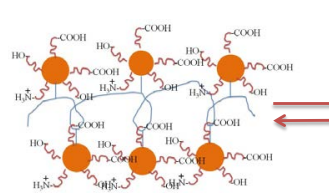

at $\mathbf{p H}<$ IEP

the net charge of the molecule is always positive

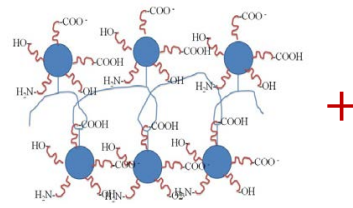

Aqueous solution of GA, $\mathbf{5 0 \%}$

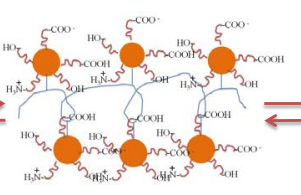

at $=$ IEP

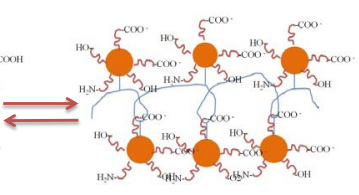

at a $\mathrm{pH}>\mathrm{IEP}$, the net charge of the molecule is always negative

(b)

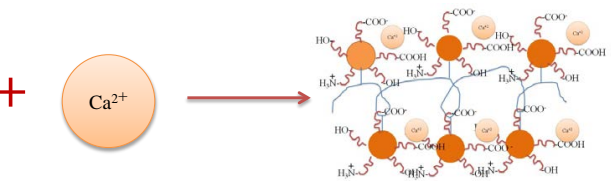

$\mathrm{GA}^{-+} \mathrm{Ca}$ complex

(c)

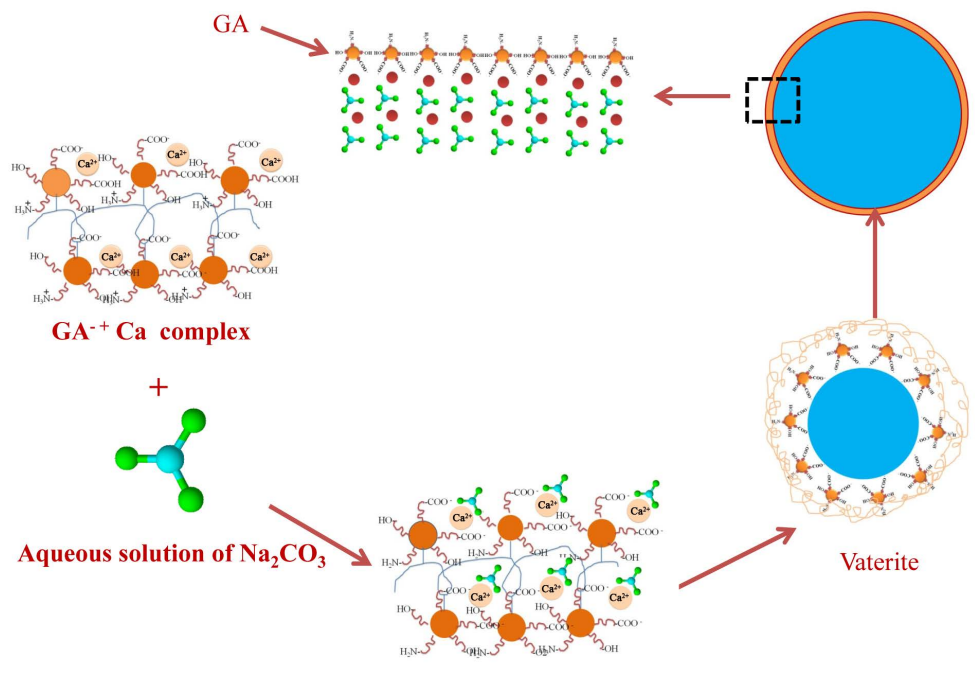

$\mathrm{GA}-\mathrm{CaCO}_{3}$ composite

(d)

Figure 11. Scheme of reaction of GA with calcium ion and precipitation of calcium carbonate, (a) behaviour of GA in aqueous solution; (b) effect of change of $\mathrm{pH}$ on the terminal functional groups of GA; (c) combination of calcium ion with GA molecules and formation of GA-Ca ${ }^{+}$complex; (d) absorption of GA on the surface of vaterite. 
multilayer formed at the surface of the particle by intermolecular hydrogen bonding between adsorbed and free GA molecules. In addition, the physical presence of the adsorbed GA molecules changes the surface charge density. Therefore, GA molecules will only bridge near the closest point of interaction between particles as a bolaform molecule, but do not help to form large aggregates with only an enhancement of steric stabilization of the small primary particles and which prevents their aggregation leading to smaller secondary particles. In addition, at high concentrations of GA, the molecules may start self-associating in solution and therefore shift the equilibrium established between the free and adsorbed GA molecules. The low concentration of calcium and carbonate increases the content of the samples prepared from vaterite phases with the concentration of gum arabic, due to the strength of gum arabic bonding with calcium carbonate particles, which hinders their conversion to calcite despite the conditions. As the concentration of reactive materials increases, the sample content of the vaterite increased and reduced the calcite content that related to increase the supersaturation conditions [65]. Actually, the stability of $\mathrm{CaCO}_{3}$ polymorphic phases mainly depends on the properties of additives and their own solubility in aqueous solution [66]. The stability of these phases' solids decreases in the following order: ACC $<$ vaterite $<$ aragonite $<$ calcite. Whereas the bulk lattice energies of calcite over aragonite is due to its higher entropy content at elevated temperatures rather than its bulk lattice energy, which favors aragonite [67]. Therefore, the stability of polymorph and morphology of $\mathrm{CaCO}_{3}$ minerals are directed by both thermodynamic and kinetic factors [68]. When the prepared vaterite retained in mother liquor there are traces of calcite phase (about 6\%) were formed due to dissolution and recrystallization process of vaterite. This explains the hiding power and strong bond between vaterite surface and GA molecules, whereas the GA formed a multilayer at the surface of the particle by intermolecular hydrogen bonding between adsorbed and free GA molecules [48] [69]. At elevated incubation temperature, the GA contaminated $\mathrm{CaCO}_{3}$ particles exhibit strong resistance towards aggregation into flocs and are stable to recrystallization process in water [48] [69]. This stabilization effect is achieved when the amount of GA is sufficient to cover the surface of all formed particles and formed the GA shell. So the uncoated particles will then undergo dissolution and recrystallization and formed traces of calcite. The formation of aragonite at concentration $0.1 \mathrm{~mol}$ of $\mathrm{Ca}^{2+}$ may related to decrease the supersaturation conditions that enhanced by elevated temperature [70].

\section{Conclusion}

The effects of gum arabic on the formation and morphology of calcium carbonate were investigated. Different analytical techniques were used to study the mineral and chemical composition, microstructure and thermal behaviour of prepared calcium carbonate. Based on the obtained results, we can provide the following. GA has ability to directing of calcium carbonate to formation vaterite. 
Increasing the GA dose enhances the molar content of vaterite. Vaterite aggregates as broccoli-or cauliflower was formed at low dose of GA and full spherical particles at high dose. The increasing of initial concentration of $\mathrm{Ca}^{2+}$ has slightly effect on the vaterite content. GA improved the stability of vaterite under aqueous solutions up to $24 \mathrm{hrs}$ and elevated temperature. SEM and TEM analysis were shown that all the prepared vaterite calcium carbonate composed from nano sized particles. GA as biomaterial can be use for preparation of bio-vaterite calcium carbonate.

\section{References}

[1] Kabalah-Amitai, L., Mayzel, B., Zaslansky, P., Kauffmann, Y., Clotens, P. and Pokroy, B. (2013) Unique Crystallographic Pattern in the Macro to Atomic Structure of Herdmania momus Vateritic Spicules. Journal of Structural Biology, 183, 191-198. https://doi.org/10.1016/j.jsb.2013.05.002

[2] El-Sheikh, S.M., El-Sherbiny, S., Barhoum, A. and Deng, Y. (2013) Effects of Cationic Surfactant during the Precipitation of Calcium Carbonate Nano-Particles on Their Size, Morphology, and Other Characteristics. Colloids and Surfaces A: Physicochemical and Engineering Aspects, 422, 44-49.

https://doi.org/10.1016/j.colsurfa.2013.01.020

[3] Qiao, L. and Feng, Q.L. (2007) Study on Twin Stacking Faults in Vaterite Tablets of Freshwater Lacklustre Pearls. Journal of Crystal Growth, 304, 253-256. https://doi.org/10.1016/j.jcrysgro.2007.02.001

[4] Kirboga, S. and Oner, M. (2013) Effect of the Experimental Parameters on Calcium Carbonate Precipitation. Chemical Engineering Transactions, 32, 2119-2124.

[5] Saraya, M.E.S.I. (2015) Effect of L (+) Ascorbic Acid and Monosodium Glutamate Concentration on the Morphology of Calcium Carbonate. Journal of Solid State Chemistry, 231, 114-122. https://doi.org/10.1016/j.jssc.2015.08.020

[6] Gamelas, J.A., Lourenço, A.F., Xavier, M. and Ferreira, P.J. (2014) Modification of Precipitated Calcium Carbonate with Cellulose Esters and Use as Filler in Papermaking. Chemical Engineering Research and Design, 92, 2425-2430. https://doi.org/10.1016/j.cherd.2014.02.003

[7] Feoktistova, N., Rose, J., Prokopović, V.Z., Vikulina, A.S., Skirtach, A. and Volodkin, D. (2016) Controlling the Vaterite $\mathrm{CaCO}_{3}$ Crystal Pores. Design of Tailor-Made Polymer Based Microcapsules by Hard Templating. Langmuir, 32, 4229-4238. https://doi.org/10.1021/acs.langmuir.6b00717

[8] Massi, M., Ogden, M.I. and Jones, F. (2012) Investigating Vaterite Phase Stabilisation by a Tetrazole Molecule during Calcium Carbonate Crystallisation. Journal of Crystal Growth, 351, 107-114. https://doi.org/10.1016/j.jcrysgro.2012.04.011

[9] Nassrallah-Aboukais, N., Boughriet, A., Laureyns, J., Gengembre, L. and Aboukais, A. (1999) Stabilization of the Vaterite Structure in the Presence of Copper (II): Thermodynamic and Spectroscopic Studies. Chemistry of Materials, 11, 44-51. https://doi.org/10.1021/cm9803399

[10] Gehrke, N., Cölfen, H., Pinna, N., Antonietti, M. and Nassif, N. (2005) Superstructures of Calcium Carbonate Crystals by Oriented Attachment. Crystal Growth and Design, 5, 1317-1319. https://doi.org/10.1021/cg050051d

[11] Hubbe, M.A. and Gill, R.A. (2016) Fillers for Papermaking: A Review of Their Properties, Usage Practices, and Their Mechanistic Role. BioResources, 11, 2886-2963. https://doi.org/10.15376/biores.11.1.2886-2963 
[12] Kuusisto, J. and Maloney, T.C. (2016) Preparation and Characterization of Corn Starch-Calcium Carbonate Hybrid Pigments. Industrial Crops and Products, 83, 294-300. https://doi.org/10.1016/j.indcrop.2016.01.026

[13] Dastjerdi, J., Motlagh, E.N. and Garmabi, H. (2017) Crystallization, Melting, and Mechanical Behavior of Calcium Carbonate-Based Nanocomposites of Crosslinked High Density Polyethylene. Polymer Composites, 38.

https://doi.org/10.1002/pc.24008

[14] Ghari, H.S. and Jalali-Arani, A. (2016) Nanocomposites Based on Natural Rubber, Organoclay and Nano-Calcium Carbonate: Study on the Structure, Cure Behavior, Static and Dynamic-Mechanical Properties. Applied Clay Science, 119, 348-357. https://doi.org/10.1016/j.clay.2015.11.001

[15] Dizaj, S.M., Barzegar-Jalali, M., Zarrintan, M.H., Adibkia, K. and Lotfipour, F. (2015) Calcium Carbonate Nanoparticles; Potential in Bone and Tooth Disorders. Pharmaceutical Sciences, 20, 175.

[16] Maleki Dizaj, S., Barzegar-Jalali, M., Zarrintan, M.H., Adibkia, K. and Lotfipour, F. (2015) Calcium Carbonate Nanoparticles as Cancer Drug Delivery System. Expert Opinion on Drug Delivery, 12, 1649-1660. https://doi.org/10.1517/17425247.2015.1049530

[17] Schmidt, S. and Volodkin, D. (2013) Microparticulate Biomolecules by Mild CaCO 3 Templating. Journal of Materials Chemistry B, 1, 1210-1218. https://doi.org/10.1039/C2TB00344A

[18] Wang, A., Yang, Y., Zhang, X., Liu, X., Cui, W. and Li, J. (2016) Gelatin-Assisted Synthesis of Vaterite Nanoparticles with Higher Surface Area and Porosity as Anticancer Drug Containers in Vitro. ChemPlusChem, 81, 194-201. https://doi.org/10.1002/cplu.201500515

[19] Saikia, J. and Das, G. (2014). Framboidal Vaterite for Selective Adsorption of Anionic Dyes. Journal of Environmental Chemical Engineering, 2, 1165-1173. https://doi.org/10.1016/j.jece.2014.04.016

[20] Chong, K.Y., Chia, C.H., Zakaria, S. and Sajab, M.S. (2014) Vaterite Calcium Carbonate for the Adsorption of Congo Red from Aqueous Solutions. Journal of Environmental Chemical Engineering, 2, 2156-2161. https://doi.org/10.1016/j.jece.2014.09.017

[21] Parakhonskiy, B., Tessarolo, F., Haase, A. and Antolini, R. (2013) Dependence of Sub-Micron Vaterite Container Release Properties on $\mathrm{pH}$ and Ionic Strength of the Surrounding Solution. In: Advances in Science and Technology, Vol. 86, Trans Tech Publications, 81-85.

[22] Katsifaras, A. and Spanos, N. (1999) Effect of Inorganic Phosphate Ions on the Spontaneous Precipitation of Vaterite and on the Transformation of Vaterite to Calcite. Journal of Crystal Growth, 204, 183-190.

https://doi.org/10.1016/S0022-0248(99)00174-8

[23] Aouad, S., Saab, E., Nassrallah-aboukaïs, N. and Abi-aad, E. (2009) The Use of Vaterite as a Trap for Metallic Ions in Water Study of Copper/Vaterite and Manganese/Vaterite Systems. Lebanese Science Journal, 10, 101-111.

[24] Islam, A.M., Phillips, G.O., Sljivo, A., Snowden, M.J. and Williams, P.A. (1997) A Review of Recent Developments on the Regulatory, Structural and Functional Aspects of Gum Arabic. Food Hydrocolloids, 11, 493-505. https://doi.org/10.1016/S0268-005X(97)80048-3

[25] Verbeken, D., Dierckx, S. and Dewettinck, K. (2003) Exudate Gums: Occurrence, Production, and Applications. Applied Microbiology and Biotechnology, 63, 10-21. https://doi.org/10.1007/s00253-003-1354-Z 
[26] Cozic, C., Picton, L., Garda, M.R., Marlhoux, F. and Le Cerf, D. (2009) Analysis of Arabic Gum: Study of Degradation and Water Desorption Processes. Food Hydrocolloids, 23, 1930-1934. https://doi.org/10.1016/j.foodhyd.2009.02.009

[27] Dauqan, E. and Abdullah, A. (2013) Utilization of Gum Arabic for Industries and Human Health. American Journal of Applied Sciences, 10, 1270. https://doi.org/10.3844/ajassp.2013.1270.1279

[28] Karaiskou, S., Blekas, G. and Paraskevopoulou, A. (2008) Aroma Release from Gum Arabic or Egg Yolk/Xanthan-Stabilized Oil-in-Water Emulsions. Food Research International, 41, 637-645. https://doi.org/10.1016/j.foodres.2008.04.004

[29] Ahmed, A.A., Musa, H.H., Fedail, J.S., Sifaldin, A.Z. and Musa, T.H. (2016) Gum Arabic Suppressed Diet-Induced Obesity by Alteration the Expression of mRNA Levels of Genes Involved in Lipid Metabolism in Mouse Liver. Bioactive Carbohydrates and Dietary Fibre, 7, 15-20. https://doi.org/10.1016/j.bcdf.2016.01.002

[30] Sukhotu, R., Guo, S., Xing, J., Hu, Q., Wang, R., Shi, X., Guo, S., et al. (2016) Changes in Physiochemical Properties and Stability of Peanut Oil Body Emulsions by Applying Gum Arabic. LWT-Food Science and Technology, 68, 432-438. https://doi.org/10.1016/j.lwt.2015.12.055

[31] Liu, S., Elmer, C., Low, N.H. and Nickerson, M.T. (2010) Effect of pH on the Functional Behaviour of Pea Protein Isolate-Gum Arabic Complexes. Food Research International, 43, 489-495. https://doi.org/10.1016/j.foodres.2009.07.022

[32] Ozturk, B., Argin, S., Ozilgen, M. and McClements, D.J. (2015) Formation and Stabilization of Nanoemulsion-Based Vitamin E Delivery Systems using Natural Biopolymers: Whey Protein Isolate and Gum Arabic. Food Chemistry, 188, 256-263. https://doi.org/10.1016/j.foodchem.2015.05.005

[33] Khalid, S.A., Musa, A.M., Saeed, A.M., Abugroun, E.A., Ahmed, E.O.S., Ghalib, M.B., Phillips, G.O., et al. (2014) Manipulating Dietary Fibre: Gum Arabic Making Friends of the Colon and the Kidney. Bioactive Carbohydrates and Dietary Fibre, 3, 71-76. https://doi.org/10.1016/j.bcdf.2014.01.005

[34] Bandyopadhyaya, R., Nativ-Roth, E., Regev, O. and Yerushalmi-Rozen, R. (2002) Stabilization of Individual Carbon Nanotubes in Aqueous Solutions. Nano Letters, 2, 25-28. https://doi.org/10.1021/n1010065f

[35] Leong, Y.K., Seah, U., Chu, S.Y. and Ong, B.C. (2001) Effects of Gum Arabic Macromolecules on Surface Forces in Oxide Dispersions. Colloids and Surfaces A: Physicochemical and Engineering Aspects, 182, 263-268. https://doi.org/10.1016/S0927-7757(00)00826-8

[36] Roque, A.C.A. and Wilson, O.C. (2008) Adsorption of Gum Arabic on Bioceramic Nanoparticles. Materials Science and Engineering: C, 28, 443-447. https://doi.org/10.1016/j.msec.2007.04.009

[37] Landon, P.B., Mo, A.H., Ramos, C.T., Gutierrez, J.J. and Lal, R. (2013) Facile, Green Synthesis of Large Single Crystal Copper Micro and Nanoparticles with Ascorbic Acid and Gum Arabic. Open Journal of Applied Sciences, 3, 332-336. https://doi.org/10.4236/ojapps.2013.35043

[38] Wu, C.C. and Chen, D.H. (2010) Facile Green Synthesis of Gold Nanoparticles with Gum Arabic as a Stabilizing Agent and Reducing Agent. Gold Bulletin, 43, 234-240. https://doi.org/10.1007/BF03214993

[39] Velikov, K.P., Zegers, G.E. and van Blaaderen, A. (2003) Synthesis and Characterization of Large Colloidal Silver Particles. Langmuir, 19, 1384-1389. https://doi.org/10.1021/la026610p 
[40] Ritchie, A.W., Watson, M.I., Turnbull, R., Lu, Z.Z., Telfer, M., Gano, J.E., Zhou, W., et al. (2013) Reversed Crystal Growth of Rhombohedral Calcite in the Presence of Chitosan and Gum Arabic. CrystEngComm, 15, 10266-10271. https://doi.org/10.1039/c3ce41543k

[41] Wilson, O.C., Blair, E., Kennedy, S., Rivera, G. and Mehl, P. (2008) Surface Modification of Magnetic Nanoparticles with Oleylamine and Gum Arabic. Materials Science and Engineering. C, 28, 438-442. https://doi.org/10.1016/j.msec.2007.04.008

[42] Kontoyannis, C.G. and Vagenas, N.V. (2000) Calcium Carbonate Phase Analysis using XRD and FT-Raman Spectroscopy. Analyst, 125, 251-255.

https://doi.org/10.1039/a908609i

[43] Wei, H., Shen, Q., Zhao, Y., Wang, D.J. and Xu, D.F. (2003) Influence of Polyvinylpyrrolidone on the Precipitation of Calcium Carbonate and on the Transformation of Vaterite to Calcite. Journal of Crystal Growth, 250, 516-524. https://doi.org/10.1016/S0022-0248(02)02484-3

[44] Shen, Y., Xie, A., Chen, Z., Xu, W., Yao, H., Li, S. and Kong, X. (2007) Controlled Synthesis of Calcium Carbonate Nanocrystals with Multi-Morphologies in Different Bicontinuous Microemulsions. Materials Science and Engineering: A, 443, 95-100. https://doi.org/10.1016/j.msea.2006.08.105

[45] Tai, C.Y. and Chen, C.K. (2008) Particle Morphology, Habit, and Size Control of $\mathrm{CaCO} 3$ using Reverse Microemulsion Technique. Chemical Engineering Science, 63, 3632-3642. https://doi.org/10.1016/j.ces.2008.04.022

[46] Chen, J. and Xiang, L. (2009) Controllable Synthesis of Calcium Carbonate Polymorphs at Different Temperatures. Powder Technology, 189, 64-69.

https://doi.org/10.1016/j.powtec.2008.06.004

[47] Mantilaka, M.M.M.G.P.G., Rajapakse, R.M.G., Karunaratne, D.G.G.P. and Pitawala, H.M.T.G.A. (2014) Preparation of Amorphous Calcium Carbonate Nanoparticles from Impure Dolomitic Marble with the Aid of Poly (Acrylic Acid) as a Stabilizer. Advanced Powder Technology, 25, 591-598. https://doi.org/10.1016/j.apt.2013.09.008

[48] Yu, S.H., Cölfen, H., Hartmann, J. and Antonietti, M. (2002) Biomimetic Crystallization of Calcium Carbonate Spherules with Controlled Surface Structures and Sizes by Double-Hydrophilic Block Copolymers. Advanced Functional Materials, 12, 541-545. https://doi.org/10.1002/1616-3028(20020805)12:8<541::AID-ADFM541>3.0.CO;2-3

[49] Xu, X., Han, J.T. and Cho, K. (2004) Formation of Amorphous Calcium Carbonate Thin Films and Their Role in Biomineralization. Chemistry of Materials, 16, 1740-1746. https://doi.org/10.1021/cm035183d

[50] Su, Y., Yang, H., Shi, W., Guo, H., Zhao, Y. and Wang, D. (2010) Crystallization and Morphological Control of Calcium Carbonate by Functionalized Triblock Copolymers. Colloids and Surfaces A: Physicochemical and Engineering Aspects, 355, 158-162. https://doi.org/10.1016/j.colsurfa.2009.12.002

[51] Trushina, D.B., Bukreeva, T.V., Kovalchuk, M.V. and Antipina, M.N. (2014) CaCO 3 Vaterite Microparticles for Biomedical and Personal Care Applications. Materials Science and Engineering: C, 45, 644-658. https://doi.org/10.1016/j.msec.2014.04.050

[52] Raz, S., Hamilton, P.C., Wilt, F.H., Weiner, S. and Addadi, L. (2003) The Transient Phase of Amorphous Calcium Carbonate in Sea Urchin Larval Spicules: The Involvement of Proteins and Magnesium Ions in Its Formation and Stabilization. Advanced Functional Materials, 13, 480-486. https://doi.org/10.1002/adfm.200304285 
[53] Dejehet, F., Idrissi, S. and Debuys, R. (1999) Magnesium and Occluded Water in Calcium Carbonate Monohydrate. Journal de Chimie Physique et de Physico-Chimie Biologique, 96, 741-753. https://doi.org/10.1051/jcp:1999168

[54] Huber, M., Stark, W.J., Loher, S., Maciejewski, M., Krumeich, F. and Baiker, A. (2005) Flame Synthesis of Calcium Carbonate Nanoparticles. Chemical Communications, No. 5, 648-650. https://doi.org/10.1039/b411725e

[55] Johnson, D.R. and Robb, W.A. (1973) Gaylussite: Thermal Properties by Simultaneous Thermal Analysis. American Mineralogist, 58, 778-784.

[56] Zhou, G.T., Jimmy, C.Y., Wang, X.C. and Zhang, L.Z. (2004) Sonochemical Synthesis of Aragonite-Type Calcium Carbonate with Different Morphologies. New Journal of Chemistry, 28, 1027-1031. https://doi.org/10.1039/b315198k

[57] Sondi, I., Salopek-Sondi, B., Škapin, S.D., Šegota, S., Jurina, I. and Vukelić, B. (2011) Colloid-Chemical Processes in the Growth and Design of the Bio-Inorganic Aragonite Structure in the Scleractinian Coral Cladocora caespitosa. Journal of Colloid and Interface Science, 354, 181-189. https://doi.org/10.1016/j.jcis.2010.10.055

[58] Perić, J., Vučak, M., Krstulović, R., Brečević, L. and Kralj, D. (1996) Phase Transformation of Calcium Carbonate Polymorphs. Thermochimica Acta, 277, 175-186. https://doi.org/10.1016/0040-6031(95)02748-3

[59] Gillis, R.B., Adams, G.G., Alzahrani, Q. and Harding, S.E. (2016) A Novel Analytical Ultracentrifugation Based Approach to the Low Resolution Structure of Gum Arabic. Biopolymers, 105, 618-625. https://doi.org/10.1002/bip.22823

[60] Roque, A.C., Bicho, A., Batalha, I.L., Cardoso, A.S. and Hussain, A. (2009) Biocompatible and Bioactive Gum Arabic Coated Iron Oxide Magnetic Nanoparticles. Journal of Biotechnology, 144, 313-320. https://doi.org/10.1016/j.jbiotec.2009.08.020

[61] Dickinson, E. (2009) Hydrocolloids as Emulsifiers and Emulsion Stabilizers. Food Hydrocolloids, 23, 1473-1482. https://doi.org/10.1016/j.foodhyd.2008.08.005

[62] Ma, F., Bell, A.E. and Davis, F.J. (2015) Effects of High-Hydrostatic Pressure and $\mathrm{pH}$ Treatments on the Emulsification Properties of Gum Arabic. Food Chemistry, 184, 114-121. https://doi.org/10.1016/j.foodchem.2015.03.075

[63] Dror, Y., Cohen, Y. and Yerushalmi-Rozen, R. (2006) Structure of Gum Arabic in Aqueous Solution. Journal of Polymer Science Part B: Polymer Physics, 44, 3265-3271. https://doi.org/10.1002/polb.20970

[64] Ouhenia, S., Chateigner, D., Belkhir, M.A., Guilmeau, E. and Krauss, C. (2008) Synthesis of Calcium Carbonate Polymorphs in the Presence of Polyacrylic Acid. Journal of Crystal Growth, 310, 2832-2841. https://doi.org/10.1016/j.jcrysgro.2008.02.006

[65] Hu, Z. and Deng, Y. (2004) Synthesis of Needle-Like Aragonite from Calcium Chloride and Sparingly Soluble Magnesium Carbonate. Powder Technology, 140, 10-16. https://doi.org/10.1016/j.powtec.2004.01.001

[66] Altay, E., Shahwan, T. and Tanoğlu, M. (2007) Morphosynthesis of CaCO 3 at Different Reaction Temperatures and the Effects of PDDA, CTAB, and EDTA on the Particle Morphology and Polymorph Stability. Powder Technology, 178, 194-202. https://doi.org/10.1016/j.powtec.2007.05.004

[67] Shen, Q., Wei, H., Zhou, Y., Huang, Y., Yang, H., Wang, D. and Xu, D. (2006) Properties of Amorphous Calcium Carbonate and the Template Action of Vaterite Spheres. The Journal of Physical Chemistry B, 110, 2994-3000. https://doi.org/10.1021/jp055063o 
[68] Liu, L., Jiang, J. and Yu, S.H. (2014) Polymorph Selection and Structure Evolution of $\mathrm{CaCO} 3$ Mesocrystals under Control of Poly (Sodium 4-Styrenesulfonate): Synergetic Effect of Temperature and Mixed Solvent. Crystal Growth and Design, 14, 6048-6056. https://doi.org/10.1021/cg5012132

[69] De Leeuw, N.H. and Parker, S.C. (1998) Surface Structure and Morphology of Calcium Carbonate Polymorphs Calcite, Aragonite, and Vaterite: An Atomistic Approach. The Journal of Physical Chemistry B, 102, 2914-2922. https://doi.org/10.1021/jp973210f

[70] Hu, Z. and Deng, Y. (2003) Supersaturation Control in Aragonite Synthesis using Sparingly Soluble Calcium Sulfate as Reactants. Journal of Colloid and Interface Science, 266, 359-365. https://doi.org/10.1016/S0021-9797(03)00699-4 